\title{
Calcium signals in the nucleus accumbens: Activation of astrocytes by ATP and succinate
}

\author{
Tünde Molnár ${ }^{1}$, Árpád Dobolyi ${ }^{2}$, Gabriella Nyitrai ${ }^{1}$, Péter Barabás ${ }^{1,3}$, László Héja ${ }^{1}$, Zsuzsa Emri ${ }^{1,4}$, Miklós Palkovits ${ }^{2}$ \\ and Julianna Kardos ${ }^{1 *}$
}

\begin{abstract}
Background: Accumulating evidence suggests that glial signalling is activated by different brain functions. However, knowledge regarding molecular mechanisms of activation or their relation to neuronal activity is limited. The purpose of the present study is to identify the characteristics of ATP-evoked glial signalling in the brain reward area, the nucleus accumbens (NAc), and thereby to explore the action of citric acid cycle intermediate succinate (SUC).

Results: We described the burst-like propagation of $\mathrm{Ca}^{2+}$ transients evoked by ATP in acute NAc slices from rat brain. Co-localization of the ATP-evoked $\mathrm{Ca}^{2+}$ signalling with immunoreactivities of the astroglia-specific gap junction forming channel protein connexin43 (CX43) and the glial fibrillary acidic protein (GFAP) indicated that the responsive cells were a subpopulation of $\mathrm{C} \times 43$ and GFAP immunoreactive astrocytes. The ATP-evoked $\mathrm{Ca}^{2+}$ transients were present under the blockade of neuronal activity, but were inhibited by $\mathrm{Ca}^{2+}$ store depletion and antagonism of the $\mathrm{G}$ protein coupled purinergic $\mathrm{P} 2 \mathrm{Y}_{1}$ receptor subtype-specific antagonist MRS2179. Similarly, $\mathrm{Ca}^{2+}$ transients evoked by the $\mathrm{P} 2 \mathrm{Y}_{1}$ receptor subtype-specific agonist 2-(Methylthio)adenosine 5'-diphosphate were also blocked by MRS2179. These characteristics implied that intercellular $\mathrm{Ca}^{2+}$ signalling originated from the release of $\mathrm{Ca}^{2+}$ from internal stores, triggered by the activation of $\mathrm{P} 2 \mathrm{Y}_{1}$ receptors. Inhibition by the gap junction blockers carbenoxolone and flufenamic acid and by an antibody raised against the gating-associated segment of Cx43 suggested that intercellular $\mathrm{Ca}^{2+}$ signalling proceeded through gap junctions. We demonstrated for the first time that extracellular SUC also evoked $\mathrm{Ca}^{2+}$ transients $\left(\mathrm{EC}_{50}=50-60 \mu \mathrm{M}\right)$ in about $15 \%$ of the ATP-responsive NAC astrocytes. By contrast to glial cells, electrophysiologically identified NAc neurons surrounded by ATP-responsive astrocytes were not activated simultaneously.

Conclusions: We concluded, therefore, that ATP- and SUC-sensitive $\mathrm{Ca}^{2+}$ transients appear to represent a signalling layer independent of NAC neurons. This previously unrecognised glial action of SUC, a major cellular energy metabolite, may play a role in linking metabolism to $\mathrm{Ca}^{2+}$ signalling in astrocytic networks under physiological and pathological conditions such as exercise and metabolic diseases.
\end{abstract}

\section{Background}

In astrocytes of the brain reward area, the nucleus accumbens (NAc; [1]), $\gamma$-hydroxybutyric acid (GHB; [2]) evoked intracellular store-reliant $\mathrm{Ca}^{2+}$ transients, independently of neuronal activity [3]. Previously, we also showed that binding sites for GHB are shared with citric acid cycle intermediate succinic acid (SUC) and the gap-

\footnotetext{
* Correspondence: jkardos@chemres.hu

'Department of Neurochemistry, Institute of Biomolecular Chemistry, Chemical Research Center, Hungarian Academy of Sciences, Pusztaszeriút 5967, 1025 Budapest, Hungary

Full list of author information is available at the end of the article
}

junction blocker carbenoxolone hemisuccinate (CBX), as disclosed in NAc membrane homogenates isolated from rat and human brain tissues [4-6]. These findings raised the possibility that SUC, similarly to GHB may also evoke $\mathrm{Ca}^{2+}$ transients in NAc astrocytes. Further, it is conceivable that the rather specific sensitivity of the SUC/GHB target site to CBX might be a sign of its functional association with connexin channels. In order to study the effect and functional significance of SUC on the $\mathrm{Ca}^{2+}$ homeostasis of NAc astrocytes, we considered that the $\mathrm{Ca}^{2+}$ bursting activity was found ATPresponsive in vivo, i.e. in Bergmann glia networks

\section{Biomed Central}


activated by the motor behaviour of the awaken animal [7]. Therefore, we sought to characterise first the ATPresponsive $\mathrm{Ca}^{2+}$ signalling amongst the astrocytes of the NAc.

ATP is known to evoke $\mathrm{Ca}^{2+}$ bursts by activation of purinergic G-protein-coupled receptors (GPCRs) in vitro [8-10] as well as in vivo [7,11-13]. Different in vitro paradigms, including locally administered ATP stimuli $(100 \mu \mathrm{M})$ were found effective to evoke $\mathrm{Ca}^{2+}$ transients [14-18]. In the present study, we investigated if locally ejected ATP $(100 \mu \mathrm{M})$ could evoke $\mathrm{Ca}^{2+}$ bursting in NAc astrocytes. Measurements were performed by combined application of confocal $\mathrm{Ca}^{2+}$ imaging, immunohistochemistry and electrophysiology in acute NAc tissue slices prepared from the rat brain. Astrocytes were identified by co-localization of astrocyte-specific antibodies raised against the astroglial gap-junction protein connexin $43(\mathrm{Cx} 43)$ and the glial fibrillary acidic protein (GFAP). Then, ATP-evoked $\mathrm{Ca}^{2+}$ bursts have been characterised by using of various drugs and agents, including gap-junction inhibitors (CBX, flufenamic acid: FFA), an antibody raised against the gating peptide segment of Cx43, purinergic P2 receptor agents such as the broadspectrum P2X and P2Y receptor antagonist suramin (SUR), $\mathrm{P}_{2} \mathrm{Y}_{1}$ subtype-specific agonist 2-(Methylthio)adenosine 5'-diphosphate (2-Me-S-ADP) and antagonist MRS2179, the $\mathrm{Na}^{+}$channel blocker tetrodotoxin (TTX) and the $\mathrm{Ca}^{2+}$ store depleting cyclopiazonic acid (CPA). Moreover, we also demonstrate for the first time the existence of SUC-responsive $\mathrm{Ca}^{2+}$ transients that overlay in a sub-population of NAc astrocytes.

\section{Results}

In selecting the NAc region of interest, we first considered area-dependent distribution of $\mathrm{Cx} 43$ protein and its co-localization with GFAP. Next, we asked if Cx43-positive NAc astrocytes were responded to local administration of ATP by $\mathrm{Ca}^{2+}$ transients. Subsequently, the hypothesis that SUC may also activate $\mathrm{Ca}^{2+}$ transients playing part in the ATP-responsive $\mathrm{Ca}^{2+}$ signals was tested. Finally, responsiveness of NAc neurons to ATP was explored.

\section{Demonstration of ATP-evoked burst-like $\mathrm{Ca}^{2+}$ signals amongst astrocytes in the NAC}

The expression and distribution of $\mathrm{Cx} 43$ have been first characterised in rat brain sections by immunohistochemistry. The staining pattern in a coronal section of a paraformaldehyde (PFA)-fixed rat brain revealed intense staining in both the shell and the core regions in the NAc (Figure 1A). High intensity of Cx43 immunolabelling was observed in the NAc as compared to adjacent brain regions (including the caudate putamen), suggesting a relatively higher level of connectivity of the astrocyte network in the NAc through this type of gapjunctions. Besides the NAc, relatively high Cx43 immunolabelling was also found in other brain areas, including several viscerosensory and limbic regions: i) medial
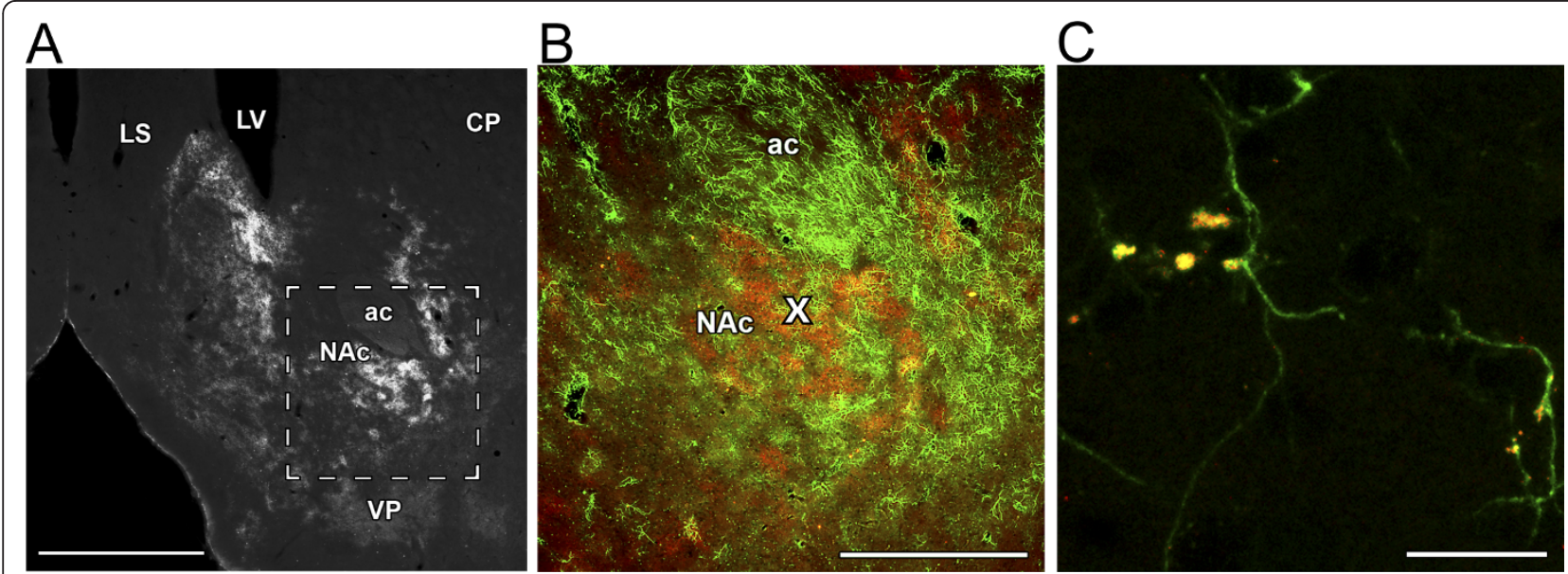

Figure 1 Cx43 is present in GFAP-containing astrocytes in the NAc. A: Cx43 immunoreactivity in a coronal section of a PFA-fixed rat brain shows relatively high intensity in the NAc, as compared to adjacent brain regions. Abbreviations: ac - anterior commissure, CP caudate-putamen, LS - lateral septal nucleus, LV - lateral ventricle, NAc - nucleus accumbens, VP - ventral pallidum. Scale bar: $1 \mathrm{~mm}$. B: Comparison of the appearance of CX43 (red) and GFAP (green) proteins in the NAc. Low magnification (scale bar: $400 \mu \mathrm{m}$ ) confocal photomicrograph of a double labelled section of a PFA-fixed rat brain. Co-localization (yellow) of Cx43 (red) and GFAP (green) immunoreactivities in the NAc suggests that Cx43 is present in GFAP-containing astrocytes in this brain region. Label " $x$ " indicates the site of ATP application. C: High magnification (scale bar: $20 \mu \mathrm{m}$ ) confocal photomicrograph of a double labelled section of a PFA-fixed rat brain. Yellow colour indicates co-localizations of Cx43 (red) and GFAP (green) immunoreactivities in the PFA-fixed NAc. 
prefrontal cortex, ii) Purkinje cell layer of the cerebellar cortex, iii) hippocampus, particularly the molecular layer of the dentate gyrus, iv) central nucleus of the amygdala, v) dorsal subdivision of the lateral septal nucleus, vi) dorsolateral subdivision of the periaqueductal gray, and vii) nucleus of the solitary tract (data not shown). Cx43 had a patchy distribution in the NAc; that is, areas with high and low intensity of labelling were intermingled (Figure 1B). Where the labelling of $\mathrm{Cx} 43$ was intense, the vast majority of $\mathrm{Cx} 43$ cells contained astrocyte marker protein GFAP immunoreactivity as shown in Figure $1 \mathrm{C}$.

In freshly prepared NAc slices from 10-14 day old male rats, $100 \mu \mathrm{M}$ ATP applied locally for $60 \mathrm{sec}$ (long ATP-puff) evoked $\mathrm{Ca}^{2+}$ transients, propagating in up to 127 cells $(44 \pm 25$ in average) in a total of 212 slices from 53 rats (Figure 2A, additional file 1). In order to characterise the dynamics of $\mathrm{Ca}^{2+}$ transients, short (2 s, Figure 2B left and middle) and long ATP (60 s, Figure $2 \mathrm{~B}$ right) puffs were compared. The period of repetitive $\mathrm{Ca}^{2+}$ transients observed after the application of the short ATP-puff (2s) occurred on a time scale similar to that of the bulky $\mathrm{Ca}^{2+}$ transient evoked by the long ATP-puff (Figure 2C). The observation suggested that the bulky $\mathrm{Ca}^{2+}$ signal can be decomposed into many repetitive $\mathrm{Ca}^{2+}$ transients providing kinetic evidence for a burst-like, coupled $\mathrm{Ca}^{2+}$ dynamics. The number of ATP responsive astrocytes was significantly higher in the NAc compared to the adjacent ventral pallidal area (Figure 2D). In line with the $\mathrm{Cx} 43$ expression pattern (Figure 1), the observation conjectured $\mathrm{Cx} 43$-related ATP-responsive $\mathrm{Ca}^{2+}$ signalling in the NAc. The burstlike $\mathrm{Ca}^{2+}$ signal, apparently not influenced by the direction of the perfusion, propagated in round or ellipsoidal waveform at an approximate $10 \mu \mathrm{m} / \mathrm{s}$ speed (Figure 2A, Additional file 1). When monitored by the glial marker dye SR101 [19,20], the diffusion of ATP was about 1.5 times faster than the speed of the $\mathrm{Ca}^{2+}$ wave propagation (Figure 2B left and middle). It is to note, that the dynamics of burst-like $\mathrm{Ca}^{2+}$ signals of NAc astrocytes can be compared with that of $\mathrm{Ca}^{2+}$ bursts of Bergmann glia in vivo $[7,13]$.

\section{Molecular dissection of ATP-evoked burst-like $\mathrm{Ca}^{2+}$ signalling}

In the lack of specific gap-junction blocker, we applied an antibody against the gating peptide segment of $\mathrm{Cx} 43$ [21] to inhibit $\mathrm{Cx} 43$ function and therefore to evaluate the involvement of gap-junctions in the ATP-evoked burst-like $\mathrm{Ca}^{2+}$ signals. Few co-localization of $\mathrm{Ca}^{2+}$ transients and $\mathrm{Cx} 43$ immunoreactivity was observed when NAc slices were pre-incubated with the $\mathrm{Cx} 43$ antibody $(7.5 \pm 2.3 \%$ of the ATP responsive cells; $N=6$ from 2 rats), suggesting that inhibition of $\mathrm{Cx} 43$ function may preclude $\mathrm{Cx} 43$ immunoreactive astrocytes to participate in the $\mathrm{Ca}^{2+}$ signal. In contrast, an about fourfold increase in co-localization of $\mathrm{Ca}^{2+}$ transients and $\mathrm{Cx} 43$ immunoreactivity was seen (Figure $3 ; 31 \pm 3 \%$ of the ATP responsive cells; $N=4$ from 4 rats), when the same antibody was applied after the application of ATP (cf. Materials and Methods). This observation indicated that the blockade of the gap-junction could prevent ATP from evoking burst-like $\mathrm{Ca}^{2+}$ signalling. Co-localizations of $\mathrm{Ca}^{2+}$ transients with $\mathrm{Cx} 43$ (Figure 3) and those of Cx43 with GFAP (Figure 1B) conclusively suggested that the ATP-evoked burst-like $\mathrm{Ca}^{2+}$ signalling occurred in NAc astrocytes.

In order to characterise the molecular determinants of ATP-evoked burst-like propagation of $\mathrm{Ca}^{2+}$ transients, effects of different gap-junction inhibitors (CBX, FFA), purinergic P2 antagonists (SUR, MRS2179), agonist 2Me-S-ADP and $\mathrm{Ca}^{2+}$ store depleting conditions (zeroadded $\mathrm{Ca}^{2+}$ with or without CPA) were investigated. To start with, the number of cells participating in the first $(100 \mu \mathrm{M}$ ATP) and the second $(100 \mu \mathrm{M}$ ATP plus test compound) ATP applications were compared (Figure $4 \mathrm{~A}$ and the Methods section). The changes in the number of ATP responsive cells in the presence of the test compounds $(\Delta \mathrm{N})$ were compared to the $\Delta \mathrm{N}$ values obtained for two consecutive ATP applications both in the absence of test compounds (control), and were given as percentage of the first ATP application (for details of the applied drug testing protocol see also the Methods section). Matching with affinities to those reported for the blockade of intercellular communication through gap junctions [22], ATP-evoked $\mathrm{Ca}^{2+}$ signalling was significantly inhibited by $100 \mu \mathrm{M}$ and $1 \mathrm{mM}$ CBX $(N=14$ from 11 rats). FFA applied in $1 \mathrm{mM}$ concentration was also found effective ( $N=3$ from 1 rat, Figure 4A left). The voltage-gated $\mathrm{Na}^{+}$channel-blocking agent TTX (10 $\mu \mathrm{M}, N=4$ from 2 rats) and the broad spectrum P2X and P2Y antagonist SUR $(100 \mu \mathrm{M}, N=5$ from 4 rats; 1 $\mathrm{mM}, N=3$ from 1 rat) were ineffective. However, the ATP puff-evoked $\mathrm{Ca}^{2+}$ transients were virtually eliminated by the selective $\mathrm{P}_{2} \mathrm{Y}_{1}$ receptor antagonist MRS2179 (100 $\mu \mathrm{M}, N=9$ from 4 rats) (Figure 4A left). The observed variability in MRS2179 effects most probably reflects the receptor/cell heterogeneity in the NAc slices prepared from 10-14 day old rats. Noteworthy, ATP only activated MRS2179-sensitive $\mathrm{P}_{2} \mathrm{Y}_{1}$ receptor in the olfactory bulb [23], as well. Locally applied P2 $\mathrm{Y}_{1}$ selective agonist 2 -Me-S-ADP $(10 \mu \mathrm{M}$, long puff; $N=6$ from 3 rats) also evoked $\mathrm{Ca}^{2+}$ transients in cells loaded with Fluo-4 acetoxymethyl ester (Fluo-4 AM), indicating the involvement of $\mathrm{P}_{2} \mathrm{Y}_{1}$ receptor in $\mathrm{Ca}^{2+}$ signalling mechanisms within NAc astrocytes (Figure 4A right). In addition, $100 \mu \mathrm{M}$ MRS2179 also blocked $\mathrm{Ca}^{2+}$ transients evoked by $2-\mathrm{Me}-\mathrm{S}-\mathrm{ADP}$ applied as ATP (Figure 4A 

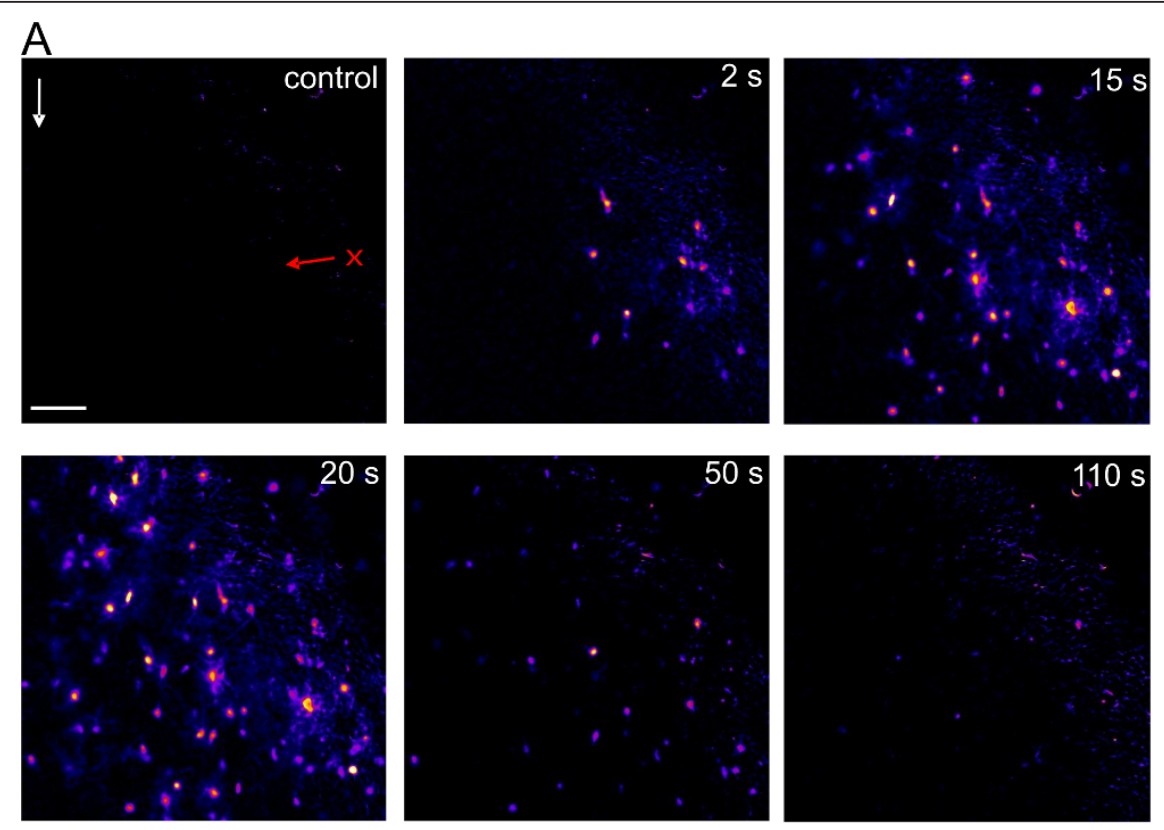

B
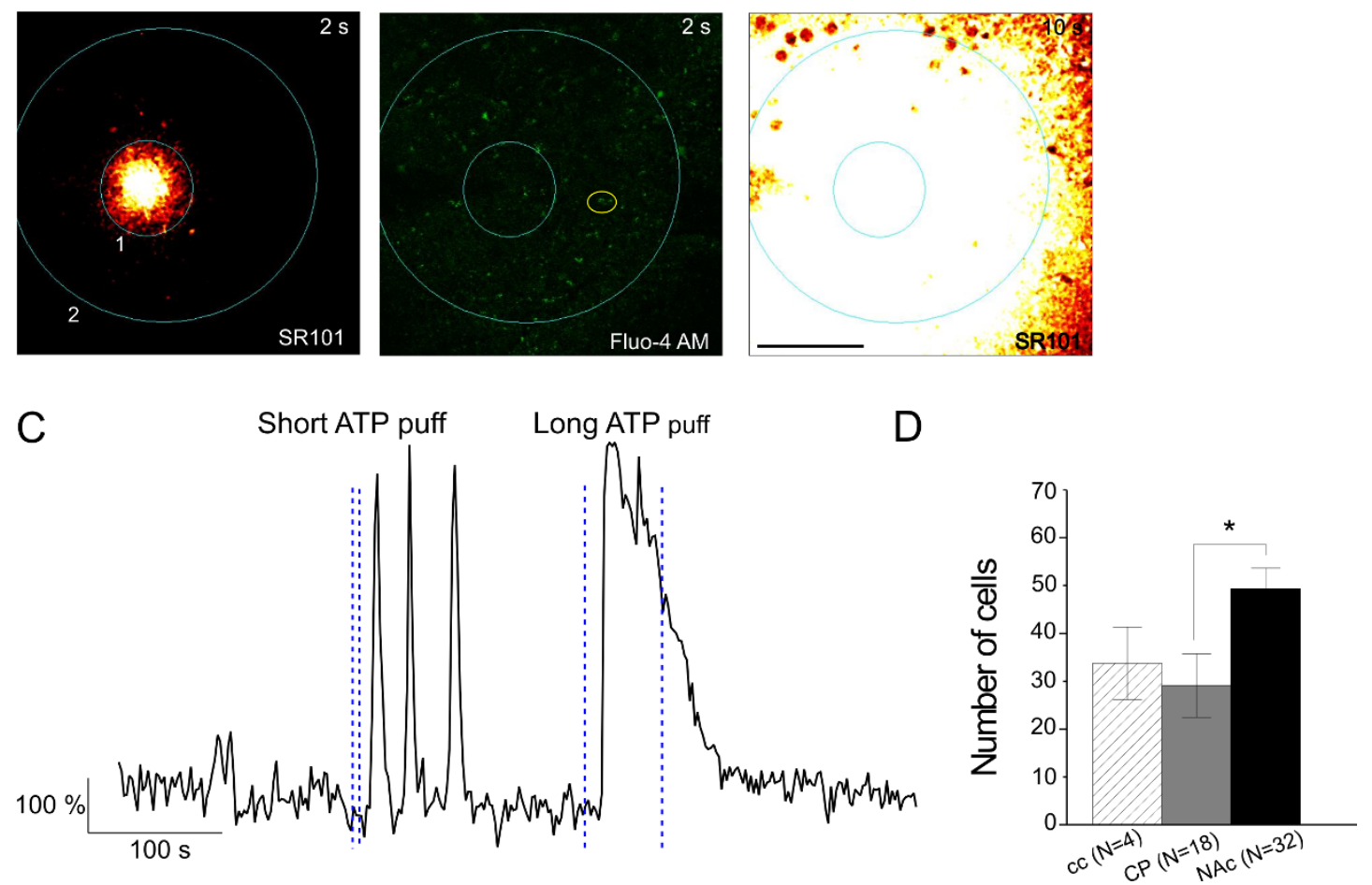

Figure 2 Demonstration of ATP-responsive astroglial $\mathrm{Ca}^{2+}$ signalling in the NAc slice. A: Time-series of Fluo-4 pseudo-coloured fluorescence images (see also Additional file 1) show propagation of $\mathrm{Ca}^{2+}$ transients induced by pressure-ejection of $100 \mu \mathrm{M}$ ATP onto the surface of the NAc slice through a 5-10 $\mu \mathrm{m}$ patch-pipette for $60 \mathrm{~s}$ (long puff). Time refers to the period passed from the beginning of the long ATP puff. Arrows indicate the origin and orientation of the ATP puff (red with X) and the direction of ACSF perfusion (white). Scale bar: $50 \mu m$. B: The area initially covered by the short (left and middle) and long (right) ATP puffs was investigated to observe which cells get a direct ATP stimulus. Representative images of the glial marker dye SR101 (100 $\mu \mathrm{M}$ dissolved in ACSF; $[19,20])$ applied together with $100 \mu \mathrm{M}$ ATP to visualize propagation of ATP puff above $630 \mathrm{~nm}$ using a $543 \mathrm{~nm}$ laser for excitation. This was done in parallel with monitoring the ATP-responsive Fluo-4 $\mathrm{Ca}^{2+}$ transients in the NAc slice. The small azure circle indicates the border of the ATP+SR101 puff for $2 \mathrm{~s}$ (short puff) and the big azure circle shows the margin of the ATP+SR101 diffusion. Yellow circle beyond the small azure circle highlight the cell responded to the short puff application of ATP. Scale bar: $100 \mu \mathrm{m}$. C: Representative $\left(\mathrm{dF} / \mathrm{F}_{0}\right)_{\max }$ Fluo-4 fluorescence plot of the cell highlighted by the yellow circled cell in panel B recorded during ATP application for $2 \mathrm{~s}$ (short puff) and for $60 \mathrm{~s}$ (long puff, cf. B). D: Number of networking cells in long ATP puffstimulated $\mathrm{Ca}^{2+}$ transients was significantly higher in the NAc when compared to the adjacent ventral pallidal area. 


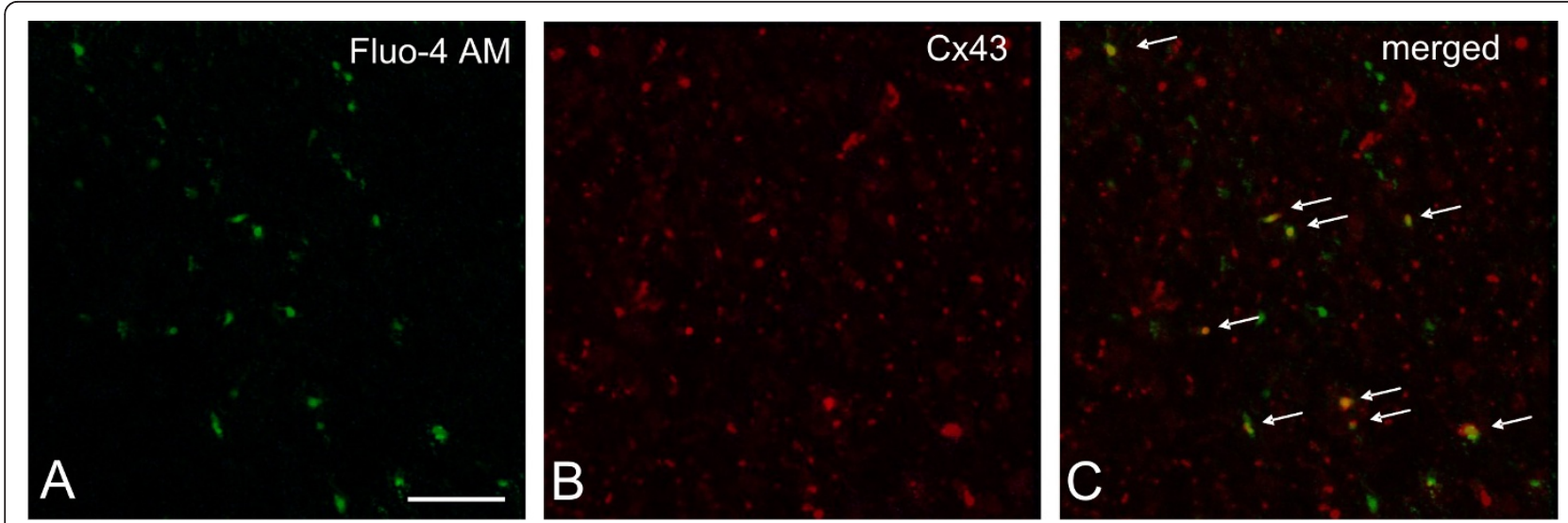

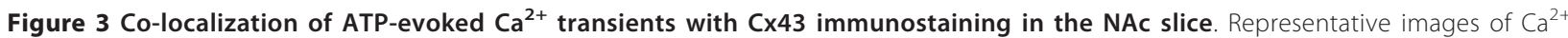
signalling in response to the long ATP puff (green, left) followed by post-calcium (cf. Methods section) Cx43 immunostaining (red, middle) demonstrated their co-localization (yellow spots marked with white arrows, right). Scale bar: $50 \mu \mathrm{m}$.

right, $N=6$ from 3 rats). Blocking effects of zero-added $\mathrm{Ca}^{2+}$ with $(N=8$ from 4 rats) or without $(N=5$ from 4 rats) the intracellular calcium store depleting CPA (10 $\mu \mathrm{M},[18])$ or CPA alone ( $N=5$ from 3 rats) (Figure $4 \mathrm{~A}$ left) suggest that the appearance of concerted $\mathrm{Ca}^{2+}$ transients stimulated by ATP in the NAc slice was reliant on the cellular $\mathrm{Ca}^{2+}$ stores. $\mathrm{Ca}^{2+}$ release from internal stores may also substantiate oscillatory dynamics observed (see Figure 2C).

In addition to the number of ATP-responsive cells, we also analysed the magnitude of the response (Figure $4 \mathrm{~B}$ and Methods section). Maximal $\mathrm{dF} / \mathrm{F}_{0}$ values for individual cells in the absence and presence of the test compounds were determined. The calculated average change in $\left(\mathrm{dF} / \mathrm{F}_{0}\right)_{\max }$ values were compared to the $\Delta\left(\mathrm{dF} / \mathrm{F}_{0}\right)_{\max }$ values obtained for two consecutive ATP applications both in the absence of test compounds (control), and were given as percentage of the first ATP application. This analysis concluded to results consistent with the cell number-based evaluation (Figure 4C). The obtained linear correlation between the cell number- and fluorescence intensity-based data $(R=0.94 \pm 0.09$, Figure $4 C)$ indicates that the $\mathrm{Ca}^{2+}$ transients are produced by an on/off trigger, corroborating $\mathrm{Ca}^{2+}$ store-operated mechanisms.

\section{SUC activates $\mathrm{Ca}^{2+}$ transients in NAc astrocytes}

We tested the hypothesis whether, in addition to ATP, SUC also activates astroglial $\mathrm{Ca}^{2+}$ signals. This was explored in measurements of the effect of SUC alone and in combination with the ATP puff-evoked $\mathrm{Ca}^{2+}$ transients characterized before. To this end, we applied the drug testing protocol described before ( $c f$. previous and Methods sections) enabling the detection of the SUC-responsive $\mathrm{Ca}^{2+}$ transients before the second ATP application. This way, the observation of the SUC- responsive cells throughout the second ATP made possible comparison of the spatiotemporal characteristics of the SUC- and ATP puff-evoked $\mathrm{Ca}^{2+}$ transients.

Indeed, superfusion of SUC initiated $\mathrm{Ca}^{2+}$ transients in a sub-population of NAc astrocytes showing $\mathrm{Ca}^{2+}$ transients in response to puffs of ATP (Figure 5A1 left). Apparently, these superimpositions of cells responding to ATP and SUC were independent of the site of activation ( $c f$. different localization and direction of ATP puff). The temporal relationships of SUC- and ATPevoked $\mathrm{Ca}^{2+}$ transients revealed similar dynamics, as shown by representative $\mathrm{dF} / \mathrm{F}_{0}$ traces ( $c f$. Figure $5 \mathrm{~A} 2$ and Figure 2C). Within the same SUC-responsive cells, $\mathrm{Ca}^{2+}$ transients appeared longer during ATP application (Figure 5A2 red and green traces) conjecturing coincident ATP activation. SUC evoked single (Figure 5A2) and repetitive $\mathrm{Ca}^{2+}$ transients, being more frequent with higher [SUC] (data not shown). Mostly double - but see orange trace in Figure 5C from Figure 5B images at $75 \mathrm{~s}$ and $120 \mathrm{~s}-\mathrm{Ca}^{2+}$ transients evoked by $50 \mu \mathrm{M}$ SUC were observed in only about $10 \%$ of slices. Similarity of $\mathrm{Ca}^{2+}$ dynamics may suggest that SUC-responsive cells could participate in burst-like $\mathrm{Ca}^{2+}$ signalling evoked by ATP. It can be relevant in this respect that the number of SUC-responsive cells did significantly tend to be higher after the ATP application $(1.3 \pm 0.3 v s .3 .2 \pm 0.5$ cells, $p$ $=0.042$, Mann-Whitney U test).

The change in the number of cells showing SUCevoked $\mathrm{Ca}^{2+}$ transients could be characterised by an $\mathrm{EC}_{50}$ value of 50-60 $\mu \mathrm{M}$ (Figure $5 \mathrm{D}, \mathrm{N}=35$ from 16 rats). The same measurements on $\mathrm{Ca}^{2+}$ transients, however, provided less $\Delta\left(\mathrm{dF} / \mathrm{F}_{0}\right)_{\max }$ data, the possible reason why the fluorescence intensity-based evaluation of the effective concentration for SUC was less conclusive (Figure $5 \mathrm{D})$. These findings were at variance with the results of the inhibition of ATP puff-evoked $\mathrm{Ca}^{2+}$ transients ( $c f$. 


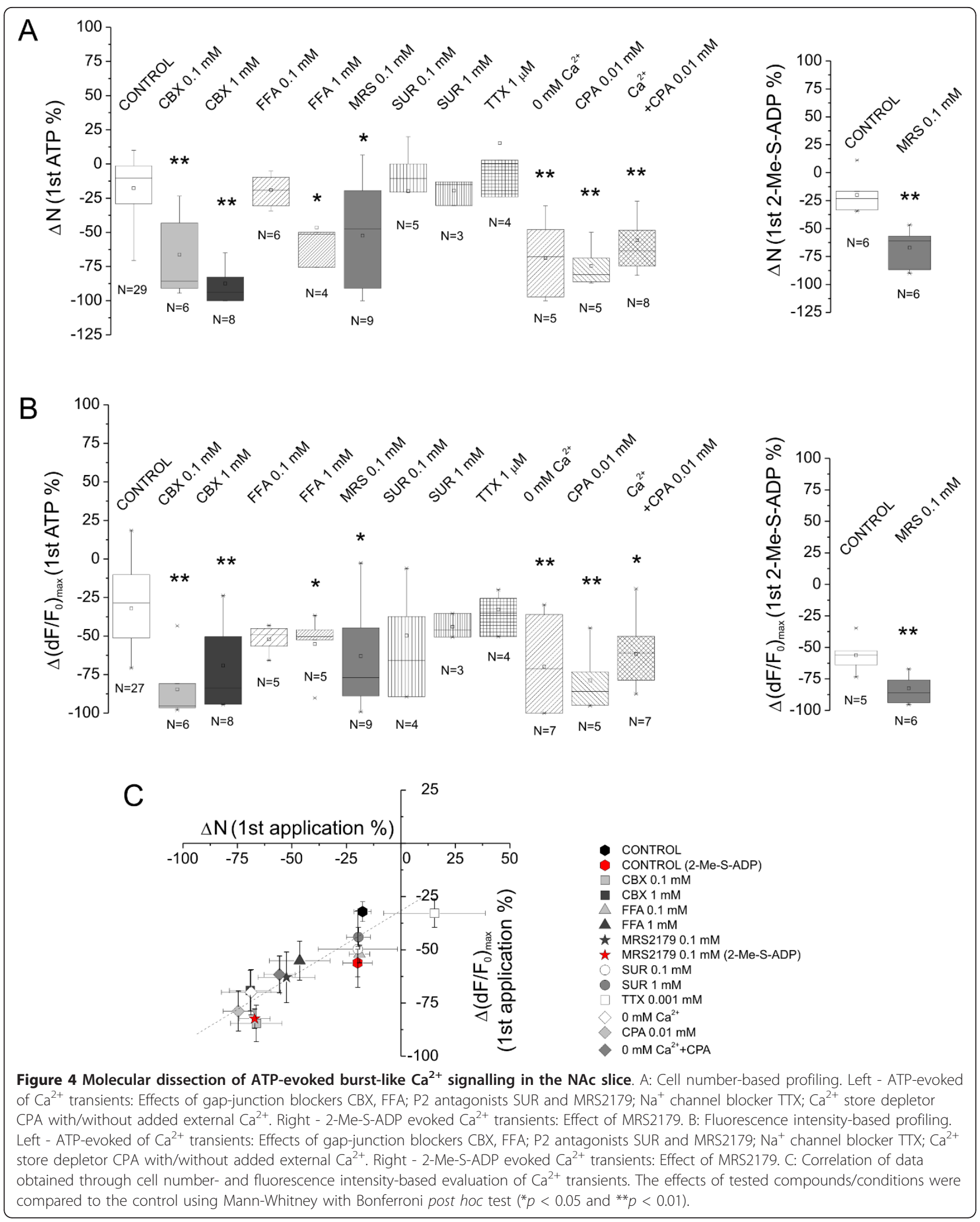




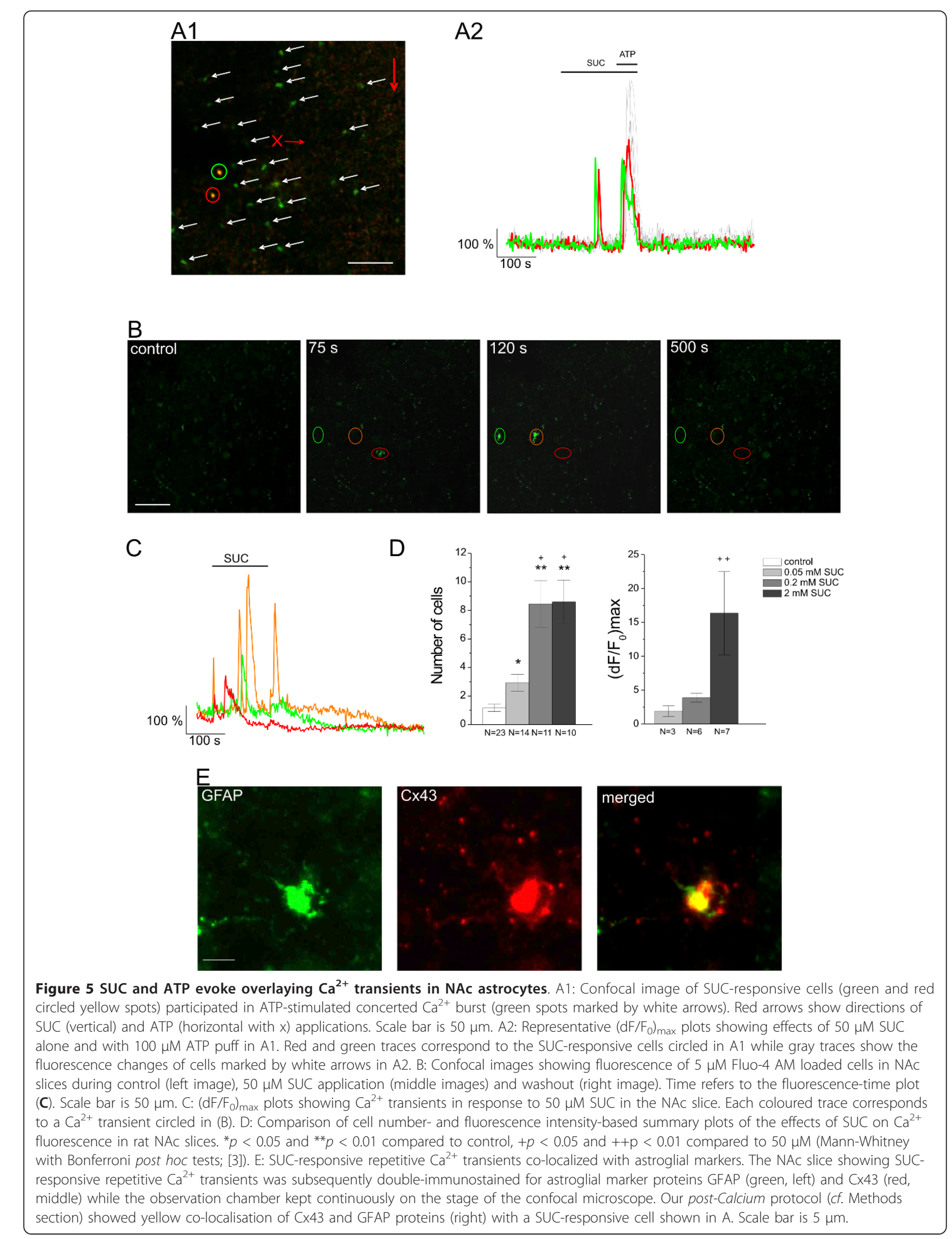

A2 
Figure 4), suggesting that in addition to the oscillatory $\mathrm{Ca}^{2+}$ dynamics, SUC may also alter fluorescence intensity through some other mechanisms making these data more vulnerable to the threshold criterion applied ( $c f$. Methods section).

Next, we asked if $\mathrm{Ca}^{2+}$ transients evoked by SUC application were occurred in astrocytes. It has already been demonstrated that the protocol used here for Fluo4. AM loading preferentially labels astrocytes [3,24]. For further identification of cells displaying SUC-responsive $\mathrm{Ca}^{2+}$ transients we applied double immunostaining for the glial marker proteins GFAP (green, Figure 5E left) and $\mathrm{Cx} 43$ (red, Figure 5E middle). Colocalization of Cx43 and GFAP proteins (yellow, Figure 5E right) identified the SUC-responsive cells as astrocytes.

\section{Neurons within the domain of burst-like $\mathrm{Ca}^{2+}$ signalling are not activated}

In order to see if neurons in the NAc participate in ATP-stimulated astroglial $\mathrm{Ca}^{2+}$ transients, we filled visually identified cells in either the shell or core regions with $\mathrm{Ca}^{2+}$ indicator dyes $(200 \mu \mathrm{M}$ Fluo-4 tetrapotassium salt, [3] or $50 \mu \mathrm{M}$ Oregon Green 488 BAPTA-1 (OGB1) hexapotassium salt, [25]). We monitored intracellular $\mathrm{Ca}^{2+}$ changes (Figure 6A green traces) and postsynaptic currents simultaneously. The cells were identified as neurons by the appearance of voltage activated fast $\mathrm{Na}^{+}$ currents during application of a voltage-ramp protocol $(-40 \mathrm{mV}$ to $+50 \mathrm{mV})$. This experimental setup allowed us to simultaneously image the $\mathrm{Ca}^{2+}$ signal and monitor the effects of ATP and/or astrocyte $\mathrm{Ca}^{2+}$ signalling on both the post-synaptic currents ( $c f$. also Methods section) and the cytosolic $\mathrm{Ca}^{2+}$ of the reporter neuron.

Although the identified reporter neurons were flooded by the long ATP puff ( $c f$. Figure $2 \mathrm{~B}$ right) and surrounded by ATP-responsive NAc astrocytes (Figure 6B left images), astroglial burst-like $\mathrm{Ca}^{2+}$ signalling caused no significant changes in cytosolic $\mathrm{Ca}^{2+}$ (Figure 6A right images; $N=15,11$ rats) of these neurons. We measured neuronal $\mathrm{Ca}^{2+}$ (Figure 6A right images and green traces) and spontaneous post-synaptic currents (i.e., amplitude and frequency) under control, ATP and distinct washout periods (Figure 6C) and found no significant changes in any of these parameters (Figure $6 \mathrm{C} ; N=18$ for 10 rats).

Similarly to ATP application (Figure 6C), postsynaptic currents of neurons within the astroglial $\mathrm{Ca}^{2+}$ signalling network did not exhibit significant changes in control frequency and amplitude $(16.3 \pm 1.5 \mathrm{pA} ; 3.0 \pm 0.9 \mathrm{~Hz})$ under $50 \mu \mathrm{M}$ SUC $(17.6 \pm 2.9 \mathrm{pA}, p>0.05 ; 2.7 \pm 1.0$ $\mathrm{Hz}, p>0.05), 50 \mu \mathrm{M}$ SUC $+\mathrm{ATP}(18.1 \pm 1.8 \mathrm{pA}, p>$ $0.05 ; 2.6 \pm 0.8 \mathrm{~Hz}, p>0.05)$ and washout $(16.4 \pm 2.8$ $\mathrm{pA}, p>0.05 ; 3.0 \pm 1.6 \mathrm{~Hz}, p>0.05)$ periods $(N=3$ from 3 rats, data not shown). These findings supported our conclusion that NAc neurons did not participate in astroglial $\mathrm{Ca}^{2+}$ signalling elicited by ATP and/or SUC.

\section{Discussion}

We described that ATP evokes burst-like propagation of $\mathrm{Ca}^{2+}$ signals amongst astrocytes in the NAc. We disclosed for the first time that SUC does also induce $\mathrm{Ca}^{2+}$ transients. We will discuss the mechanisms of $\mathrm{Ca}^{2+}$ signalling amongst astrocytes in the NAc and their possible relation to neuronal activity. The potential importance of metabolites related to brain energy state regulating $\mathrm{Ca}^{2+}$ signals will also be speculated.

\section{Intercellular $\mathrm{Ca}^{2+}$ signalling through $\mathrm{Cx} 43$ containing astrocytes in the NAC}

The ATP-evoked burst-like $\mathrm{Ca}^{2+}$ signal apparently propagates through astrocytes coupled by gap-junctions [26-28]. More extensive $\mathrm{Ca}^{2+}$ signalling in response to the localized ATP stimuli in the NAc as compared to nearby brain areas may possibly be due to the more abundant presence of $\mathrm{Cx} 43$ protein and gap-junctions thereupon. Our observations also suggest that $\mathrm{Cx} 43$ containing gap-junctions participate in burst-like $\mathrm{Ca}^{2+}$ signalling and were expressed only in astrocytes [29]. Note, however, that co-localization of Cx43 and GFAP may also be associated with reactive astrocytes [30] or radial glia [31].

Astroglial burst-like $\mathrm{Ca}^{2+}$ signals are known to propagate via two mechanisms [26,27]: transfer of cytosolic inositol $(1,4,5)$-trisphosphate $\left(\mathrm{IP}_{3}\right)$ directly from cell to cell through gap junction channels and release of ATP onto extracellular purinergic receptors. The CBX-sensitive $\mathrm{Ca}^{2+}$ signal is coupled with the ATP-triggered enhancement of $\mathrm{IP}_{3}$ and its diffusion through gap-junction channels between neighbouring astrocytes [32]. Another possible way of CBX- and FFA-sensitive propagation of the $\mathrm{Ca}^{2+}$ signal involves sequential activation of cation channels by ATP that is released through gapjunction hemichannels into the extracellular space $[33,34]$. These CBX-sensitive $\mathrm{Ca}^{2+}$ waves could be blocked by SUR, a polysulfonated napthylurea used as a broad spectrum antagonist at purine-activated P2X channels and G-protein-coupled P2Y receptors [35-37]. In our experiments SUR $(100 \mu \mathrm{M}, 1 \mathrm{mM})$ did not block the ATP-activated $\mathrm{Ca}^{2+}$ bursts significantly, although it is known to antagonize P2X receptors in the $1-100 \mu \mathrm{M}$ range [36]. Nevertheless, our results corroborate previous data suggesting that SUR, the widely used antagonist of the effects of ATP at P2 purinoceptors, also induces calcium inducible calcium release (CICR) and increases open channel probability of ryanodine receptor channels [38-42]. These findings can explain the apparent ineffectiveness of SUR as a P2 antagonist by the 


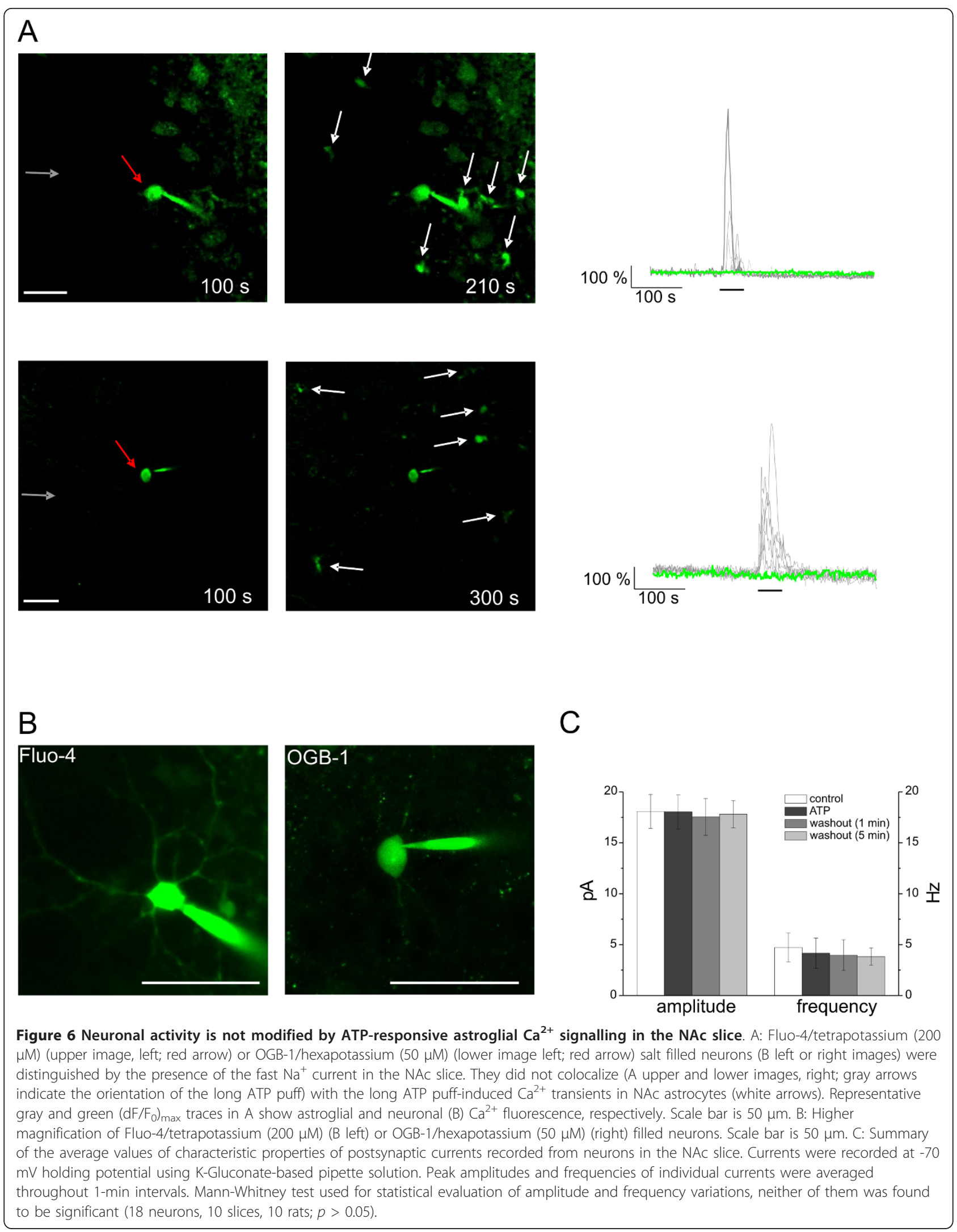


opposing SUR-induced $\mathrm{Ca}^{2+}$ enhancements through the direct activation of intracellular $\mathrm{Ca}^{2+}$ stores.

In contrast, the blockade of both ATP- and the $\mathrm{P}^{2} \mathrm{Y}_{1}$ selective 2-Me-S-ADP-evoked $\mathrm{Ca}^{2+}$ transients by the $\mathrm{P}_{1} \mathrm{Y}_{1}$ selective antagonist MRS2179 indicated that the astroglial burst-like $\mathrm{Ca}^{2+}$ signal may possibly be evoked by activation of the $\mathrm{P}_{2} \mathrm{Y}_{1}$ receptor subtype in the NAc. The observed variability in MRS2179 effects may be related to developmental changes of $\mathrm{P}^{2} \mathrm{Y}_{1}$ receptors [43] resulting through receptor/cell heterogeneity within the shell/core regions of NAc slices prepared from 10-14 day old rats. In addition, endogenous SUC may have a co-stimulatory role in ATP-induced astroglial $\mathrm{Ca}^{2+}$ signalling and, by (partially) antagonizing the effects of the $\mathrm{P}_{1} \mathrm{Y}_{1}$ inhibitor MRS2179 as observed with human platelets [44], may contribute to the inter-slice/rat variability observed. It may be significant in this regard, that coapplication of SUC and ATP apparently results in more durable $\mathrm{Ca}^{2+}$ transients, conjecturing coincidence detection.

As discussed before, $\mathrm{Ca}^{2+}$ store mobilization, underlying propagating astroglial burst-like $\mathrm{Ca}^{2+}$ transients can occur via ${\mathrm{P} 2 Y_{1}}_{1}$ receptor activation in the NAc. Both the inhibitor profile (blockade by CBX, FFA and Cx43 antibody) and dynamics of ATP-evoked $\mathrm{Ca}^{2+}$ waves suggest cell-to-cell signalling through the gap-junction-coupled astrocytes in the NAc. Low FFA efficacy may be due to the possible enhancement of intracellular $\mathrm{Ca}^{2+}$ by FFA acting at type 6 transient receptor potential canonical channel (TRPC6) $[45,46]$.

As outlined above, the alternative ATP-driven way of signal propagation $[26,27,32-34]$ may not be excluded purely on the basis of the apparent lack of SUR blockade of ATP-evoked $\mathrm{Ca}^{2+}$ signals. Binding of CBX to SUC receptor [4-6], however, could be accounted for some blockade of ATP-driven $\mathrm{Ca}^{2+}$ signal propagation as detailed below.

\section{NAC astrocytes respond to SUC}

SUC binding sites have previously been disclosed in rat forebrain and human NAc membrane homogenates $[4,6]$, however, their functions have not been assigned yet. Identity of SUC-sensitive GHB [5] and GHB-sensitive SUC [4] binding sites raised the possibility to relate SUC and different GHB actions [47-50]. Importantly, the binding site of GHB/SUC interacts with CBX [4-6], a blocker of gap-junctions that are major players of astroglial $\mathrm{Ca}^{2+}$ signalling [51]. We have also shown previously that $\mathrm{GHB}$ activates intracellular store-dependent $\mathrm{Ca}^{2+}$ transients in NAc astrocytes [3]. Here we report, that SUC induced repetitive $\mathrm{Ca}^{2+}$ transients occur in a subpopulation of $\mathrm{Cx}_{4} 3^{+}$and $\mathrm{GFAP}^{+}$cells responding to ATP with burst-like $\mathrm{Ca}^{2+}$ signals involving gap-junctions. SUC may bind to a purinergic $\mathrm{G}$ protein coupled receptor (GPCR) subtype or some other SUC-responsive membrane receptor such as SUCNR1 (GPCR91). Interestingly, the SUCNR1 gene is located on chromosome 3 as part of a cluster of seven GPCRs in close vicinity to the genes for $\mathrm{P}_{2} \mathrm{Y}_{1}$ [52]. Also, direct effect of SUC on gap-junctions cannot be excluded. The SUCNR1 has recently been shown to regulate cellular functions implicated in renal blood pressure regulation $[44,53]$ and lipolysis of white adipose tissue [54]. In addition, the SUCNR1 may also have a role for immunity, hyperglycemia, retinal neovascularization, ischemic liver injury and hematopoiesis as reviewed recently [44]. The presence of SUCNR1 has been demonstrated in human platelets and megakaryocytes [44], in various cells of distal nephron [55] and in cardiomyocytes [56].

The concentration of SUC in plasma [57-59] increases with exercise [60], metabolic acidosis [61], hypertension and metabolic diseases [62] from $5 \mu \mathrm{M}$ up to $125 \mu \mathrm{M}$. These data suggest that the tissue concentration of SUC can be high enough to induce astroglial $\mathrm{Ca}^{2+}$ transients characterised by the $\mathrm{EC}_{50}$ value for SUC-responsive cells within the range of 50-60 $\mu \mathrm{M}$. Using arachidonic acid, ADP and SUC as platelet agonists, aggregation in response to SUC alone was highly variable with only $29 \%$ of donors showing a (mostly delayed) platelet response [44]. In contrast, SUC reproducibly and concentration-dependently enhanced platelet aggregation in response to low concentrations of exogenous ADP [44]. Assuming the presence of SUCNR1 and $\mathrm{P}_{2} \mathrm{Y}_{1}$ in astrocyte membrane, we conjecture co-stimulatory roles played by endogenous SUC and ATP within the brain. Such a coincidence detection performed by astrocytes could explain why astrocytic $\mathrm{Ca}^{2+}$ transients may be dramatically affected by pathological conditions associated with intense neuronal firing [63].

\section{Signalling layer independent of neurones}

It has been reported, that mechanically evoked astrocytic $\mathrm{Ca}^{2+}$ waves mediated by the release of ATP and the activation of $\mathrm{P} 2$ receptors in hippocampal cultures down-regulate excitatory glutamatergic synaptic transmission in an ATP-dependent manner [64]. Using astrocyte-specific inducible transgenic mice (dnSNARE mice), it has been evidenced that by the release of ATP, which accumulates as adenosine, astrocytes tonically suppress synaptic transmission in acutely isolated hippocampal slices [65]. Causal linkage between reduced activation of adenosine receptors and surface expression of NMDA receptors has also been evidenced [[66] and references cited there]. We assumed therefore, that by using ATP puff, which may also reduce activity of NAc neurons, we could isolate 'autonomous' astrocytic $\mathrm{Ca}^{2+}$ signalling. Indeed, the loading pattern of the $\mathrm{Ca}^{2+}$ indicator Fluo-4 $\mathrm{AM}[3,24]$ and the presence of $\mathrm{Cx} 43$ protein in cells 
responding to SUC/ATP by $\mathrm{Ca}^{2+}$ transients identified them as astrocytes.

Propagation of the $\mathrm{Ca}^{2+}$ signal in ellipsoidal and/or radial waveform at a speed of approximately $10 \mu \mathrm{m} / \mathrm{s}$ in NAc astrocytes is comparable to the time evolution of Bergmann glia $\mathrm{Ca}^{2+}$ transients, as previously recorded from fixed location in vitro $[9,10]$ and in vivo $[7,13]$. The similarity suggests both phenomena involve ATPtriggered release of $\mathrm{Ca}^{2+}$ from intracellular stores, as found. The type of glial $\mathrm{Ca}^{2+}$ signalling classified as bursts persisted after application of TTX in the cerebellar Bergmann glia in vivo [7] and NAc astrocytes in vitro (this work). Unchanged postsynaptic currents and an invariable cytosolic $\mathrm{Ca}^{2+}$ level of neurons within the astrocyte network that exhibited concerted $\mathrm{Ca}^{2+}$ bursts support our conclusion that the ATP evokes astroglial burst-like $\mathrm{Ca}^{2+}$ signals independently of neuronal activity in the NAc. In this respect, ATP/SUC-evoked astrocytic $\mathrm{Ca}^{2+}$ transients differ from the ones dependent on the metabotropic Glu recptor subtype 5, leading to the activation of the NR2B subunit containing N-Me-D-Asp receptors (NMDARs) of medium spiny neurones in the NAc or the striatum [17]. Our conclusion upholds previous findings by us [3] and others [[28], reviewed in [63]], suggesting the existence of "autonomous" activation of astroglial $\mathrm{Ca}^{2+}$ signals. Remarkably, glial $\mathrm{Ca}^{2+}$ bursting activity observed in the cerebellum of awake, behaving animal is also found to be independent of neuronal activity [7].

Findings obtained with the NAc model of glia activation described in this work do not exclude, however, that $\mathrm{Ca}^{2+}$ signalling involving ATP/SUC sensing cells might be a unique feature of the NAc. We may also assume such a signalling route in other brain areas exhibiting extensive $\mathrm{Cx} 43$ expression. The way of $\mathrm{Ca}^{2+}$ signalling is probably characteristic of a given brain region [28]. $\mathrm{Ca}^{2+}$ bursts have been shown in cultured astrocytes [34], white matter tract [67], cerebellum [7] and cortical brain slices $[28,68,69] . \mathrm{Ca}^{2+}$ bursts in the neocortex depend on gap-junction coupling of astrocytes and are not influenced by neuronal activity while in the corpus callosum $\mathrm{Ca}^{2+}$ signalling requires ATP-release mechanism but not gap-junction expression [28]. These pathways are not independent from each other and most probably linked to the cell types participated in $\mathrm{Ca}^{2+}$ signalling [19]. In the retina, astrocytic $\mathrm{Ca}^{2+}$ wave is dependent on gap-junctions, while the wave propagation between astrocytes and Müller cells requires ATPrelease mechanism [70]. The expression of the major gap-junction protein of astrocytes $\mathrm{Cx} 43$ influences purinergic receptor expression in the spinal cord astrocytes [71]. These examples rather support the view that glial $\mathrm{Ca}^{2+}$ bursts may represent a signalling layer independent of neurons.
The issue of independence as opposed to interdependence of glial and neuronal activities is related to the question of astrocytic release of signalling molecules that may also modulate synaptic transmission, a process called gliotransmission. As outlined before, there are several indications, that astrocytes do affect synaptic activity through the release of ATP, Glu, D-Ser, tumour necrosis factor alpha [[63-66,72] and references cited] or uptake of Glu [73,74] and GABA [74]. It is to note, that the physiological relevance of gliotransmission in longterm potentiation (LTP) was called into question [[75,76], see also [77] for additional references]. In contrast, $\mathrm{Ca}^{2+}$-dependent release of D-Ser from an astrocyte affecting NMDAR-dependent plasticity was demonstrated by clamping internal $\mathrm{Ca}^{2+}$ in individual astrocytes of the CA1 area of the hippocampus [77].

\section{Conclusions}

Diverse cellular pathways of astroglial $\mathrm{Ca}^{2+}$ signals are differently pronounced in various brain regions and they can also co-occur. Besides, the initial stimuli are likely a determinant of the relevant physiological function being involved.

The findings of the present study describe for the first time the $\mathrm{Ca}^{2+}$ signals evoked in astrocytes of the brain reward area, the nucleus accumbens, by the citric acid cycle intermediate SUC. We also identify these SUC-responsive $\mathrm{Ca}^{2+}$ signals in ATP-evoked burst-like intercellular $\mathrm{Ca}^{2+}$ signalling. We provide evidence that ATP- and SUC-responsive glial $\mathrm{Ca}^{2+}$ signals are independent on neuronal activity therefore apparently represent a signalling layer independent of NAc neurons.

ATP-induced calcium responses have previously been shown in cortical and hippocampal astrocytes whereas succinate-induced calcium signals had not been described in astrocytes. This previously unrecognized glial action of the major cellular energy metabolite SUC may represent a link between brain energy states and $\mathrm{Ca}^{2+}$ signalling in astrocytic networks.

\section{Methods}

\section{Ethics statement}

Animal care and preparations were in accordance with the Helsinki declaration, the European Council Directive of 24 November 1986 (86/609/EEC), the Hungarian Animal Act 1998, and were associated local guidelines, as approved by the Institutional Animal Care and Use Committee (approval ID: MÁB 1.51.4.).

\section{Buffers and test compounds}

Slice preparing buffer contained in mM: 250 sucrose, 2 $\mathrm{KCl}, 1.25 \mathrm{KH}_{2} \mathrm{PO}_{4}, 10 \mathrm{MgSO}_{4}, 2 \mathrm{CaCl}_{2}, 16 \mathrm{NaH}_{2} \mathrm{CO}_{3}$ and 10 glucose. Artificial cerebrospinal fluid (ACSF) 
contained in mM: $129 \mathrm{NaCl}, 2 \mathrm{KCl}, 1.25 \mathrm{KH}_{2} \mathrm{PO}_{4}, 1$ $\mathrm{MgSO}_{4}, 2 \mathrm{CaCl}_{2}, 16 \mathrm{NaHCO}_{3}$ and 10 glucose.

The following drugs were applied via the ACSF perfusion: SUC, GHB, CBX, another gap-junction blocker FFA (purchased from Sigma-Aldrich, Budapest, Hungary); P2X/P2Y receptor antagonist SUR, the $\mathrm{P}_{2} \mathrm{Y}_{1}$ receptor antagonist MRS2179, the endoplasmic $\mathrm{Ca}^{2}$ +-ATPase inhibitor CPA, and TTX (from Tocris, Bristol, UK). Agonists ATP and 2-Me-S-ADP were locally applied through a glass micropipette (Sigma-Aldrich, Budapest, Hungary).

Fluorescence indicators Fluo-4 AM, Fluo-4 tetrapotassium salt, OGB-1 hexapotassium salt, propidium iodide (PI), SR101 and pluronic acid were purchased from Molecular Probes (Eugene, USA). Stock solutions of ester fluorescence indicators prepared in DMSO were diluted to $0.1 \%$ DMSO in the staining solution.

\section{Acute slice preparation and dye loading}

Coronal slices from the forebrain through the NAc and the caudate putamen $(\mathrm{CP})$ were prepared for the imaging experiments. Young, 10-14 day-old male Wistar rats were decapitated and the brains were quickly removed. The forebrains were serially cut into $300 \mu \mathrm{m}$ thick coronal sections (Vibratome, Technical Products International Inc., St. Louis, MO, USA). The slices were collected in ice-cold preparation buffer and incubated for one hour under humidified gas-mixture carbogen $\left(5 \% \mathrm{CO}_{2}+95 \% \mathrm{O}_{2}\right)$ atmosphere in an interface-type holding chamber containing warmed $\left(35^{\circ} \mathrm{C}\right)$ ACSF. After preincubation in $2 \%$ pluronic acid containing ACSF for 2 minutes, slices were further incubated with $5 \mu \mathrm{M}$ Fluo-4 AM in ACSF at $35^{\circ} \mathrm{C}$ in the dark under humidified carbogen $\left(5 \% \mathrm{CO}_{2}+95 \% \mathrm{O}_{2}\right)$ atmosphere, for one hour [3]. In order to monitor cell death, several slices were exposed to double dye-loading protocol, performed by adding $7.5 \mu \mathrm{M}$ PI (excitation: $534 \mathrm{~nm}$, emission: $570-$ $600 \mathrm{~nm}$ ) to the Fluo-4 AM containing ACSF. In order to allow for cleavage of the AM ester group of Fluo-4, slices were transferred to dye-free ACSF at least $30 \mathrm{~min}$ utes before the start of the experiment [78].

\section{Confocal imaging and drug testing protocol}

We used Fluo-4 AM for quantifying astroglial $\mathrm{Ca}^{2+}$ concentrations in the $100 \mathrm{nM}$ to 1 microM range [3]. Fluo4 offers high fluorescence emission due to its greater absorption near $488 \mathrm{~nm}$, and a large dynamic range for reporting $\left[\mathrm{Ca}^{2+}\right]$ around a $\mathrm{K}_{\mathrm{d}}\left(\mathrm{Ca}^{2+}\right)$ of $345 \mathrm{nM}$ [79]. Fluorescence recordings of changes in the intracellular $\mathrm{Ca}^{2+}$ ion level in cells loaded with Fluo-4 AM were performed, with an upright epifluorescent microscope (Olympus BX61WI, Olympus, Budapest, Hungary) equipped with the FluoView300 confocal laser-scanning system (Olympus, Budapest, Hungary) using $20 \times(0.5$ numerical aperture) or 60 (0.9 numerical aperture) water immersion objectives (for details, see [3]). Image acquisition rate was controlled by a computer running Tiempo software for FluoView300 (Olympus, Budapest, Hungary).

Freshly isolated slices were transferred to the submerge-type recording chamber mounted on the stage of the microscope and were superfused with carbogenated $\left(5 \% \mathrm{CO}_{2}+95 \% \mathrm{O}_{2}\right)$ ACSF $(3 \mathrm{ml} / \mathrm{min}$, room temperature). Serial scanning of slices were made at $488 \mathrm{~nm}$ excitation wavelengths and emitted green fluorescence was collected through a 510-530 nm bandpass filter. $\mathrm{Ca}^{2}$ ${ }^{+}$transients were initiated by application of SUC in the perfusion or by pressure-ejection of $100 \mu \mathrm{M}$ ATP in ACSF through a glass micropipette (5-10 $\mu \mathrm{m}$ diameter) on the slice surface. Fluorescence intensity changes within a $355 \times 355 \mu \mathrm{m}$ field containing approximately 100 Fluo-4 AM loaded cells around the area of the ATP puff, were followed over a 10-minute interval (2 s/ image).

Two 10-minute-long consecutive recordings were made from each slice with a 20 -minute resting time between the two recordings. ATP was applied $3 \mathrm{~min}$ after the beginning of each 10-minute-long recording period. All tested drugs (CBX, FFA, SUR, MRS2179, CPA, TTX) and/or zero-added $\mathrm{Ca}^{2+}$ condition were applied throughout the second 10-minute-long recording period and were present at the time of the second ATP application. Co-localisation of $\mathrm{Ca}^{2+}$ transients evoked by the 1st and the 2nd ATP puffs indicated similarity of $\mathrm{Ca}^{2+}$ dynamics (Figure 7A), making them strictly comparable. The number of cells showing $\mathrm{Ca}^{2+}$ increase at approximately $15-30 \mu \mathrm{m}$ below the surface of the NAc slice was also similar in consecutive ATP applications $(44 \pm 25$ cells, Figure 7B).

Images taken during the ATP application were summed and the average of images taken during the control period was subtracted as a background. The Fluo-4 loaded cells were identified by using custom written algorithms in Matlab under strict visual control. The intensity changes in individual cells were calculated as $d F / F_{0}$. To identify ATP responsive cells, the standard deviances of the control periods of the $\mathrm{dF} / \mathrm{F}_{0}$ traces $\left(\mathrm{SD}_{\text {control }}\right)$ were calculated and the traces with $\left(\mathrm{dF} / \mathrm{F}_{0}\right)$ max,ATP $>5 * \mathrm{SD}_{\text {control }}$ were selected. The number of cells with fluorescence intensity changes above the threshold was counted to determine the number of responsive cells $(\mathrm{N})$ and the average of their maximal $\mathrm{dF} / \mathrm{F}_{0}$ values $\left(\left(\mathrm{dF} / \mathrm{F}_{0}\right)_{\max }\right)$ during the ATP application period was used to assess the magnitude of the response. The changes in $\mathrm{N}$ and $\left(\mathrm{dF} / \mathrm{F}_{0}\right)_{\max }$ values $\left(\Delta \mathrm{N}\right.$ and $\Delta\left(\mathrm{dF} / \mathrm{F}_{0}\right)_{\max }$, respectively) obtained in the presence of test compounds were normalized to the corresponding $\mathrm{N}$ and $\left(\mathrm{dF} / \mathrm{F}_{0}\right)_{\max }$ values obtained in the absence of the test compounds 

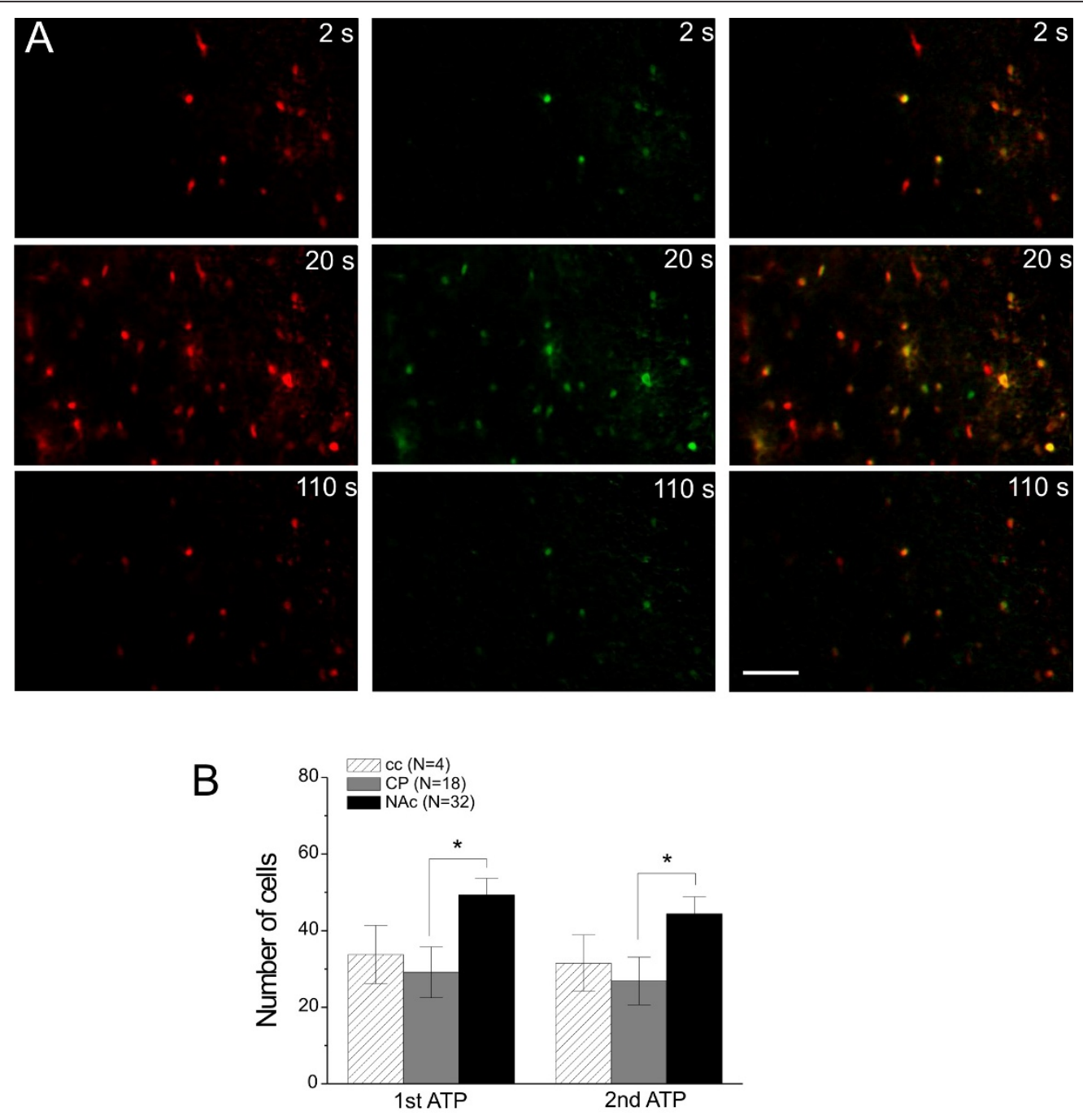

C
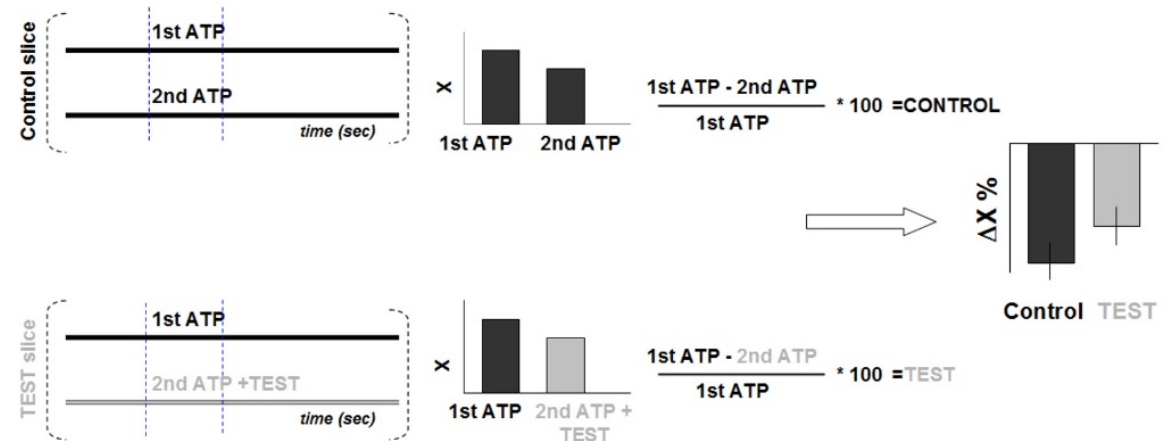

Control TEST

Figure $7 \mathrm{Ca}^{2+}$ transients evoked by consecutive ATP puffs applied onto the surface of the NAc slice. A: Time series of $\mathrm{Ca}^{2+}$ transients in response of the 1st (left, red) and the 2 nd (middle, green) ATP-puff applied by pressure-ejection of $100 \mu \mathrm{M}$ ATP through a 5-10 $\mu \mathrm{M}$ diameter patch-pipette for $60 \mathrm{~s}$ (long puff). Time refers to the time elapsed from the beginning of the ATP applications. Overlaying $\mathrm{Ca}^{2+}$ transients (right, yellow) suggest similarity of $\mathrm{Ca}^{2+}$ dynamics of consecutive ATP puffs. Scale bar is $50 \mu \mathrm{m}$. B: Comparison of $\mathrm{Ca}^{2+}$ signalling after the 1 st and 2nd ATP application in the corpus callosum $(N=4)$, caudate putamen $(N=18)$ and NAc $(N=32)$. Data represent means \pm S.E.M. (Mann-Whitney with Bonferroni post hoc test: ${ }^{*} p<0.05$. C: The protocol applied for testing effects of different drugs/conditions on ATP-stimulated Ca ${ }^{2+}$ elevations in slices from the NAc. The difference between the two recordings in the number of cells $(\Delta N)$ or maximal fluorescence intensity $\Delta$ $\left(\mathrm{dF} / \mathrm{F}_{0}\right)_{\max }$ was expressed as the percentage of the effects of the first (control) stimulus (100 $\mu \mathrm{M}$ ATP or $10 \mu \mathrm{M}$ 2-Me-S-ADP) application. 
(Figure 7C). We observed that the number of ATP responsive cells and their maximal response were reduced in the second ATP application even if the test compounds were not present. Therefore to take this reduction into account, the calculated $\Delta \mathrm{N}$ and $\Delta\left(\mathrm{dF} / \mathrm{F}_{0}\right)$ max values for each condition were compared (ANOVA) to $\Delta \mathrm{N}$ and $\Delta\left(\mathrm{dF} / \mathrm{F}_{0}\right)_{\max }$ values obtained for two consecutive ATP applications both in the absence of test compounds (control in Figure 4).

Data presented are mean \pm S.E.M., with $\mathrm{N}$ denoting the number of slices in a given experimental condition. Statistical analysis was performed using the non-parametric Mann-Whitney test with Bonferroni post hoc test (OriginLab Co., Northampton, UK) and $\mathrm{p}<0.05$ was considered statistically significant. If otherwise stated, the effects of different treatments were compared to the control.

\section{Electrophysiology}

Whole cell patch clamp recordings were performed both in the shell and the core areas of the NAc by using a MultiClamp 700A amplifier (Axon CNS, Molecular Devices, Sunnyvale, California, USA). Signals were lowpass filtered at $2 \mathrm{kHz}$ and digitized at $10 \mathrm{kHz}$ (Digidata1320A, Axon Instruments). Cells selected by their visual appearance were identified as neurons by the presence of voltage activated fast $\mathrm{Na}^{+}$currents during application of a voltage ramp protocol -40 to $+50 \mathrm{mV}$ (pClamp8, Axon Instruments). 6-8 Mc pipettes pulled from borosilicate glass capillaries were filled with an intracellular solution (containing in mM: $135 \mathrm{~K}-$ Gluconate, $10 \mathrm{NaCl}, 0.05 \mathrm{CaCl}_{2}, 2$ adenosine-triphosphate $\mathrm{Mg}^{2+}$ salt, 10 4-(2-hydroxyethyl)piperazine-1-ethanesulfonic acid (HEPES); pH 7.3 (set with $1 \mathrm{~N} \mathrm{KOH}$ ). In order to visualize and monitor cytosolic $\mathrm{Ca}^{2+}$ of patched neurons, $200 \mu \mathrm{M}$ Fluo-4 tetrapotassium salt or $50 \mu \mathrm{M}$ OGB-1 hexapotassium salt (excitation: $488 \mathrm{~nm}$, emission: $510-530 \mathrm{~nm}$ for both dyes) was added to the intracellular solution. Cells (input resistance: $166 \pm 13 \mathrm{M} \Omega$ ) were clamped to $-70 \mathrm{mV}$ without corrections for liquid junction potential $(-15 \mathrm{mV})$. At this potential inward spontaneous postsynaptic currents were recorded. If signs of seal deterioration or cell closure occurred, the recordings were discarded. The first $10 \mathrm{~min}$ of each recording were used for monitoring stabilization of the baseline. Then, a 1-minute duration control period, followed by ATP application (1 min), and a washout period (5-10 $\mathrm{min})$ were recorded.

Spontaneous postsynaptic currents (PSCs) were analyzed using Mini Analysis software (Synaptosoft, Decatur, USA; http://www.synaptosoft.com) in 4 data segments (1 min, each) recorded prior to, at the ATP application, washout after ATP application and latewashout periods. The automatically detected events (threshold: $10 \mathrm{pA}$ ) were verified by visual inspection. Multiple comparisons were done with the non-parametric Mann-Whitney test (OriginLab Co., Northampton, UK). Statistical significance was defined as $\mathrm{p}<0.05$. The data are presented as mean \pm S.E.M.

\section{Tissue processing for immunohistochemistry}

Adult, male Wistar rats ( $\mathrm{n}=3$ ) (200-250 g body weight; Charles Rivers Laboratories, Hungary) were deeply anesthetized with a mixture containing $0.2 \mathrm{ml} / 300 \mathrm{~g}$ b. w. ketamine $(100 \mathrm{mg} / \mathrm{ml})$ and $0.2 \mathrm{ml} / 300 \mathrm{~g}$ b.w. xylazine $(20 \mathrm{mg} / \mathrm{ml})$, and perfused transcardially with $150 \mathrm{ml} \mathrm{sal-}$ ine followed by $300 \mathrm{ml}$ of ice-cold $4 \%$ paraformaldehyde in phosphate buffer, pH 7.0 (PB). Brains were removed and postfixed in the same fixative solution for $24 \mathrm{~h}$, and transferred to PB containing 20\% sucrose for 2 days. Serial coronal sections were cut at $50 \mu \mathrm{m}$ on a sliding microtome (SM 2000R, Leica Microsystems, Nussloch, Germany) between $+4.0 \mathrm{~mm}$ to $0 \mathrm{~mm}$ from the level of the bregma. Sections were collected in PB containing $0.1 \%$ sodium azide and stored at $4{ }^{\circ} \mathrm{C}$ until further processing.

\section{Cx43 immunohistochemistry}

Free-floating sections were immunolabeled for $\mathrm{Cx} 43$ using an affinity-purified rabbit polyclonal antiserum raised against the carboxy terminal 362-382 peptide segment KPSSRASSRASSRPRPDDLEI of Cx43 (Abcam, Cambridge, UK, catalogue number: ab11370). Brain sections were pretreated in $\mathrm{PB}$ containing $0.5 \%$ Triton $\mathrm{X}$ 100 and $3 \%$ bovine serum albumin for $1 \mathrm{~h}$. Then, they were incubated with a primary antibody against $\mathrm{Cx} 43$ (1:1250) in PB containing $0.5 \%$ Triton X-100 and 3\% bovine serum albumin and $0.1 \%$ sodium azide for $48 \mathrm{~h}$ at room temperature. Sections were then incubated in biotin-conjugated donkey anti-rabbit secondary antibody at 1:1000 (Jackson Immunoresearch, West Grove, PA) for $2 \mathrm{~h}$, followed by incubation in avidin-biotin-horseradish peroxidase complex $(\mathrm{ABC})$ at 1:500 (Vectastain ABC Elite kit, Vector Laboratories, Burlingame, CA) for $2 \mathrm{~h}$. Then, sections were treated with either $0.02 \%$ diaminobenzidine (Sigma) or fluorescein isothiocyanate (FITC)-tyramide (1:8000) with $0.003 \% \mathrm{H}_{2} \mathrm{O}_{2}$ in Tris- $\mathrm{HCl}$ buffer $(0.05 \mathrm{M}, \mathrm{pH} 8.2)$ for $6 \mathrm{~min}$. After washing, the sections were mounted on positively charged slides (Superfrost Plus, Fisher Scientific) and coverslipped with either Cytoseal 60 (Stephens Scientific, Riverdale, NJ, USA) or in antifade medium (Prolong Antifade Kit, Molecular Probes).

\section{Cx43 and GFAP double immunohistochemistry}

Free-floating sections were first immunolabeled for Cx43 using FITC-tyramide amplification immunohistochemistry, as described above. Then, sections were 
incubated overnight in a mouse monoclonal anti-GFAP, a marker of astrocytes (1:250; catalogue number: SC33673, Santa Cruz Biotechnology, Santa Cruz, CA). Subsequently, sections were incubated in Alexa 594 donkey anti-mouse secondary antibody (1:500; Molecular Probes) for $2 \mathrm{~h}$, then mounted and coverslipped, as described above. Sections were examined using an Olympus BX60 light microscope also equipped with fluorescent epi-illumination. Images were captured at $2048 \times 2048$ pixel resolution with a SPOT Xplorer digital CCD camera (Diagnostic Instruments, Sterling Heights, MI) using 4$20 \times$ objectives. Confocal images were acquired with a Nikon Eclipse E800 confocal microscope equipped with a BioRad Radiance 2100 Laser Scanning System using 20$60 \times$ objectives (at an optical thickness of 1-3 $\mu \mathrm{m}$ ). Contrast and sharpness of the images were adjusted using the "levels" and "sharpness" commands in Adobe Photoshop CS 8.0. Colours were adjusted so that $\mathrm{Cx} 43$ appeared red and GFAP was green. Full resolution was maintained until the photomicrographs were cropped and assembled for printing, at which point images were adjusted to a resolution of $300 \mathrm{dpi}$.

\section{Post-calcium imaging immunohistochemistry protocol for Cx43 and GFAP}

In order to identify the cell types involved in $\mathrm{Ca}^{2+}$ bursts, the brain slices were immunostained with antibodies for astrocyte marker proteins (Cx43 and GFAP). However, Fluo-4 signal could not be preserved through fixation with either $0.4 \%$ paraformaldehyde or $40 \mathrm{mg} / \mathrm{ml}$ EDAC (1-ethyl-3-(3-dimethylaminopropyl)-carbodiimide, Sigma-Aldrich; Dawling and Deitmer, 2002). Therefore, co-localization between SUC/ATP-responsive cells and cell type markers could not be resolved. Hence we opted to perform the in situ immunostaining in nonfixed slices directly after the $\mathrm{Ca}^{2+}$ imaging protocol. Slices used previously to measure $\mathrm{Ca}^{2+}$ changes in response to SUC/ATP application were treated as follows: upon completion of the calcium-imaging experiments, each slice was kept in its original position in the recording chamber (using a ballast) and incubated with Cx43 (1:300) and GFAP (1:200) primary antibodies for $30 \mathrm{~min}$, at room temperature. After $3 \times 10$ minute washing in ACSF, the slice was incubated with Chromeo 546 goat anti-rabbit (1:100 Abcam, Cambridge, UK, catalogue number: ab60317) secondary antibody and Alexa 488 donkey anti-mouse (1:100, Molecular Probes) secondary antibody in ACSF for $30 \mathrm{~min}$, at room temperature. This was followed by $3 \times 10$ minute washing in ACSF. Serial Z-scans of Cx43- (excitation: $543 \mathrm{~nm}$, emission: 570-600 nm) and GFAP- (excitation: $488 \mathrm{~nm}$, emission: 510-530 $\mathrm{nm}$ ) labelled slices were acquired between the slice surface and the maximal penetration depth of the antibodies (approximately 60-70 $\mu \mathrm{m}$ from the surface) through a $20 \times$ objective $(1 \mu \mathrm{m} / \mathrm{step})$. Since the fluorescence emission of both Fluo-4 and Alexa-488 dyes are collected in the 510-530 nm range, GFAP-specific staining was obtained by subtracting the Fluo-4 fluorescence from the GFAP immunolabelling signal, at each $\mathrm{Z}$ depth. Optical sections from identical depths of Fluo- 4 and $C x 43$ images were merged along the $Z$ axis. Single cells and glia filaments that showed double immunolabelling were recorded through a $60 \times$ objective and Z-scans were performed by alternating the excitation wavelengths between $543 \mathrm{~nm}(\mathrm{Cx} 43)$ and $488 \mathrm{~m}$ (GFAP) using Tiempo software for FluoView300, at each depth $(0.1 \mu \mathrm{m} / \mathrm{step})$. Images were processed using ImageJ 1.44 [80] and Adobe Photoshop CS 8.0 image analysis software.

\section{Additional material}

Additional file 1: $\mathrm{Ca}^{2+}$ signalling evoked by ATP in the acute NAC slice from the rat brain. Movie of time measurement showing ATP (100 $\mu \mathrm{M})$ application onto a Fluo-4 AM loaded acute NAc slice $(300 \mu \mathrm{m})$. ATP was applied for $60 \mathrm{~s}$ (long puff) through a glass micropipette right above the tissue surface. Image acquisition frequency was $2 \mathrm{~s}$ in depth of 25 $\mu \mathrm{m}$ from the slice surface. Olympus FluoView300 software collected .tiff file stacks were coloured and converted to avi file by ImageJ 1.44 (32bit) image processing and analysis software [80]. ATP-responsive cells were counted by using an ImageJ macro developed to average stacks before the time of ATP application and to subtract this average from every stack of the 10 minute-long recording. In this way, we got a 10minute-long movie showing only the cells that had a fluorescence intensity change.

\section{Acknowledgements}

The authors thank Erzsébet Kútiné Fekete and Ildikó Pál (Department of Neurochemistry, Institute of Biomolecular Chemistry, Chemical Research Center, Hungarian Academy of Sciences) for excellent technical assistance and interpretation of data, respectively. Authors TM, GNY, PB, LH, ZSE and JK were supported by grants 1/A/005/2004 MediChem2, GVOP-3.2.1.-2004-040210/3.0 Transporter Explorer AKF-050068, TECH-09-Al-2009-0117 NanoSen9 and CRC-HAS-2009-Nanotransport. Authors AD and MP were supported by the grant TECH-09-Al-2009-0117 NanoSen9.

\section{Author details}

'Department of Neurochemistry, Institute of Biomolecular Chemistry, Chemical Research Center, Hungarian Academy of Sciences, Pusztaszeriút 5967, 1025 Budapest, Hungary. ${ }^{2}$ Neuromorphological and Neuroendocrine Research Laboratory, Semmelweis University and Hungarian Academy of Sciences, Túzoltó utca 58, 1094 Budapest, Hungary. ${ }^{3}$ Department of Ophthalmology, University of Utah, 65 Mario Capecchi Drive, Salt Lake City, UT 84132, USA. ${ }^{4}$ Department of Zoology, Eszterházy Károly College, Leányka utca 6, 3300 Eger, Hungary.

\section{Authors' contributions}

TM carried out the calcium imaging studies and drafted the manuscript. TM and $\mathrm{LH}$ performed the statistical analysis. AD carried out the immunoassays. GNY performed the electrophysiological studies. PB participated in the design of the study and data analysis. LH, EZS and MP participated in the interpretation of data and helped to draft the manuscript. JK conceived of the study, and participated in its design and coordination and helped to draft the manuscript. All authors read and approved the final manuscript.

Received: 28 June 2011 Accepted: 3 October 2011 Published: 3 October 2011 


\section{References}

1. Berridge KC, Kringelbach ML: Affective neuroscience of pleasure: reward in humans and animals. Psychopharmacol 2008, 199:457-480.

2. Rumigny JF, Maitre M, Cash C, Mandel P: Regional and subcellular localization in rat brain of the enzymes that can synthesize gammahydroxybutyric acid. J Neurochem 1981, 36:1433-1438.

3. Molnár T, Antal K, Nyitrai G, Emri Zs: $\gamma$-Hydroxybutyrate (GHB) induces $\mathrm{GABA}_{\mathrm{B}}$ receptor independent intracellular $\mathrm{Ca}^{2+}$ transients in astrocytes, but has no effect on $\mathrm{GHB}$ or $\mathrm{GABA}_{B}$ receptors of medium spiny neurons in the nucleus accumbens. Neurosci 2009, 162:268-281.

4. Molnár T, Barabás P, Héja L, Fekete EK, Lasztóczi B, Szabó P, Nyitrai G, Simon-Trompler E, Hajós F, Palkovits M, Kardos J: Gamma-hydroxybutyrate binds to the synaptic site recognizing succinate monocarboxylate: a new hypothesis on astrocyte-neuron interaction via the protonation of succinate. J Neurosci Res 2008, 86:1566-1576.

5. Molnár T, Fekete EK, Kardos J, Simon-Trompler E, Palkovits M, Emri Zs: Metabolic GHB precursor succinate binds to gamma-hydroxybutyrate receptors: characterization of human basal ganglia areas nucleus accumbens and globus pallidus. J Neurosci Res 2006, 84:27-36.

6. Molnár T, Visy J, Simon A, Moldvai I, Temesvári-Major E, Dörnyei G, Kútiné Fekete EK, Kardos J: Validation of high-affinity binding sites for succinic acid through distinguishable binding of gamma-hydroxybutyric acid receptor-specific NCS 382 antipodes. Bioorg Med Chem Letters 2008, 18:6290-6292

7. Nimmerjahn A, Mukamel EA, Schnitzer MJ: Motor behavior activates Bergmann glial networks. Neuron 2009, 62:400-412.

8. Stout $C E$, Costantin JL, Naus CC, Charles AC: Intercellular calcium signalling in astrocytes via ATP release through connexin hemichannels. J Biol Chem 2002, 277:10482-10488.

9. Beierlein $M$, Regehr WG: Brief bursts of parallel fiber activity trigger calcium signals in Bergmann glia. J Neurosci 2006, 26:6958-6967.

10. Piet $R$, Jahr CE: Glutamatergic and purinergic receptor-mediated calcium transients in Bergmann glial cells. J Neurosci 2007, 27:4027-4035

11. Hirase H, Qian L, Barthó P, Buzsáki G: Calcium dynamics of cortical astrocytic networks in vivo. PLoS Biology 2004, 2:0494-0499.

12. Takata $\mathrm{N}$, Hirase $\mathrm{H}$ : Cortical layer 1 and layer $2 / 3$ astrocytes exhibit distinct calcium dynamics in vivo. PLOS ONE 2008, 3:e2525.

13. Hoogland TM, Kuhn B, Gobel W, Huang W, Nakai J, Helmchen F, Flint J, Wang SS: Radially expanding transglial calcium waves in the intact cerebellum. Proc Natl Acad Sci USA 2009, 106:3496-3501.

14. Barry VA, Cheek TR: Extracellular ATP triggers two functionally distinct calcium signalling pathways in P C12 cells. J Cell Sci 1994, 107:451-462

15. Li Y, Holtzclaw LA, Russell JT: Müller cell $\mathrm{Ca}^{2+}$ waves evoked by purinergic receptor agonists in slices of rat retina. J Neurophysiol 2001, 85:986-994.

16. Zur Nieden R, Deitmer JW: The role of metabotropic glutamate receptors for the generation of calcium oscillations in rat hippocampal astrocytes in situ. Cerebral Cortex 2006, 16:676-687.

17. D'Ascenzo M, Fellin T, Terunuma M, Revilla-Sanchez R, Meaney DF, Auberson YP, Moss SJ, Haydon PG: mGluR5 stimulates gliotransmission in the nucleus accumbens. Proc Natl Acad Sci USA 2007, 104:1995-2000.

18. Fischer W, Appelt K, Grohmann M, Franke H, Nörenberg W, Illes P: Increase of intracellular $\mathrm{Ca}^{2+}$ by $\mathrm{P} 2 \mathrm{X}$ and $\mathrm{P} 2 \mathrm{Y}$ receptor-subtypes in cultured cortical astroglia of the rat. Neurosci 2009, 160:767-783.

19. Matthias K, Kirchhoff F, Seifert G, Huttmann K, Matyash M, Kettenmann H, Steinhauser C: Segregated expression of AMPA-type glutamate receptors and glutamate transporters defines distinct astrocyte populations in the mouse hippocampus. J Neurosci 2003, 23:1750-1758.

20. Kafitz KW, Meier SD, Stephan J, Rose CR: Developmental profile and properties of sulforhodamine 101-labeled glial cells in acute brain slices of rat hippocampus. J Neurosci Methods 2008, 1691:84-92.

21. Sosinsky GE, Solan JL, Gaietta GM, Ngan L, Lee GJ, Mackey MR, Lampe PD: The C-terminus of connexin43 adopts different conformations in the Golgi and gap-junction as detected with structure-specific antibodies. Biochem J 2007, 408:375-385.

22. Ye Z-C, Wyeth MS, Baltan-Tekkok S, Ransom BR: Functional hemichannels in astrocytes: a novel mechanism of glutamate release. J Neurosci 2003, 23:3588-3596.

23. Sosinsky GE, Solan JL, Gaietta GM, Ngan L, Lee GJ, Mackey MR, Lampe PD: New evidence for purinergic signalling in the olfactory bulb: $A_{2 A}$ and $P_{2} Y_{1}$ receptors mediate intracellular calcium release in astrocytes. FASEB J 2007, 22:2368-2378.
24. Parri HR, Gould TM, Crunelli V: Spontaneous astrocytic $\mathrm{Ca}^{2+}$ oscillations in situ drive NMDAR-mediated neuronal excitation. Nat Neurosci 2001, 8:803-812

25. Power JM, Sah P: Nuclear calcium signalling evoked by cholinergic stimulation in hippocampal CA1 pyramidal neurons. J Neurosci 22:3454-3462.

26. Bennett MV, Contreras JE, Bukauskas FF, Sáez JC: New roles for astrocytes: gap-junction hemichannels have something to communicate. Trends Neurosci 2003, 26:610-617.

27. Verkhratsky A: Glial calcium signalling in physiology and pathophysiology. Acta Pharmacol Sin 2006, 27:773-780

28. Haas B, Schipke CG, Peters O, Söhl G, Willecke K, Kettenmann H: Activitydependent ATP-waves in the mouse neocortex are independent from astrocytic calcium waves. Cerebral Cortex 2006, 16:237-246.

29. Nadarajah B, Thomaidou D, Evans WH, Parnavelas JG: Gap-junctions in the adult cerebral cortex: regional differences in their distribution and cellular expression of connexins. J Comp Neurol 1996, 376:326-342.

30. Ridet J, Alonso G, Chauvet N, Chapron J, Koenig J, Privat A: Immunocytochemical characterization of a new marker of fibrous and reactive astrocytes. Cell Tissue Res 1996, 283:39-49.

31. Kunze A, Congreso MR, Hartmann C, Wallraff-Beck A, Hüttmann K, Bedner $P$, Requardt R, Seifert G, Redecker C, Willecke K, Hofmann A, Pfeifer A, Theis M, Steinhäuser C: Connexin expression by radial glia-like cells is required for neurogenesis in the adult dentate gyrus. Proc Natl Acad Sci USA 2009, 106:11336-11341.

32. Sanderson MJ, Charles AC, Dirksen ER: Mechanical stimulation and intercellular communication increases intracellular $\mathrm{Ca}^{2+}$ in epithelial cells. Cell Regul 1990, 18:585-596.

33. Hassinger TD, Guthrie PB, Atkinson PB, Bennett MV, Kater SB: An extracellular signalling component in propagation of astrocytic calcium waves. Proc Natl Acad Sci USA 1996, 93:13268-13273.

34. Arcuino G, Lin JH, Takano T, Liu C, Jiang L, Gao Q, Kang J, Nedergaard M: Intercellular calcium signalling mediated by point-source burst release of ATP. Proc Natl Acad Sci USA 2002, 99:9840-9845.

35. Evans RJ, Lewis C, Buell G, Valera S, North RA, Surprenant A Pharmacological characterization of heterologously expressed ATP-gated cation channels (P2X purinoceptors). Mol Pharmacol 1995, 48:178-183.

36. Ralevic $V$, Burnstock G: Receptors for purines and pyrimidines. Pharmacol Rev 1998, 50:413-492.

37. von Kügelgen I, Wetter A: Molecular pharmacology of P2Y-receptors Naunyn-Schmiedeberg's Arch Pharmacol 2000, 362:310-323.

38. Matsuoka I, Zhou Q, Ishimoto H, Nakanishi H: Extracellular ATP stimulates adenylyl cyclase and phospholipase $C$ through distinct purinoceptors in NG108-15 cells. Mol Pharmacol 1995, 47:855-862.

39. Hohenegger M, Matyash M, Poussu K, Herrmann-Frank A, Sarközi S, Lehmann-Horn F, Freissmuth M: Activation of the skeletal muscle ryanodine receptor by suramin and suramin analogs. Mol Pharmacol 1996, 50:1443-1453.

40. Sitsapesan R, Williams AJ: Modification of the conductance and gating properties of ryanodine receptors by suramin. J Membr Biol 1996, 153:93-103.

41. Verkhratsky A: Physiology and pathophysiology of the calcium store in the endoplasmic reticulum of neurons. Physiol Rev 2005, 85:201-279.

42. Gurung IS, Martinez-Pinna J, Mahaut-Smith MP: Novel consequences of voltage-dependence to G-protein-coupled $\mathrm{P} 2 \mathrm{Y}_{1}$ receptors. British J Pharmacol 2008, 154:882-889.

43. Rubini $P$, Pinkwart C, Franke $H$, Gerevich Z, Nörenberg W, Illes P: Regulation of intracellular $\mathrm{Ca}^{2+}$ by $\mathrm{P}_{2} \mathrm{Y}_{1}$ receptors may depend on the developmental stage of cultured rat striatal neurons. J Cell Physiol 2006, 209:81-93.

44. Spath B, Ansen A, Bokemeyer C, Langer F: Succinate reverses in-vitro platelet inhibition by acetylsalicylic acid and $\mathrm{P} 2 \mathrm{Y}$ receptor antagonists. Platelets 2011, 1-9.

45. Foster RR, Welsh GI, Satchell SC, Marlow RD, Wherlock MD, Pons D, Mathieson PW, Bates DO, Saleem MA: Functional distinctions in cytosolic calcium regulation between cells of the glomerular filtration barrier. Cell Calcium 2010, 48:44-53.

46. Fellner SK, Arendshorst WJ: Angiotensin II-stimulated $\mathrm{Ca}^{2+}$ entry mechanisms in afferent arterioles: role of transient receptor potential canonical channels and reverse $\mathrm{Na}^{+} / \mathrm{Ca}^{2+}$ exchange. Am J Physiol Renal Physiol 2008, 294:F212-219. 
47. Bessman SP, Fishbein WN: Gamma-hydroxybutyrate, a normal brain metabolite. Nature 1963, 200:1207-1208.

48. Wong CG, Bottiglieri T, Snead OC: GABA, gamma-hydroxybutyric acid, and neurological diseases. Ann Neurol 2003, 54:S3-S12.

49. Wong CG, Gibson KM, Snead OC: From the street to the brain: neurobiology of the recreational drug gamma-hydroxybutyric acid. Trends Pharmacol Sci 2004, 25:29-34.

50. Camacho A, Matthews SC, Murray B, Dimsdale JE: Use of GHB compounds among college students. Am J Drug Alcohol Abuse 2005, 31:601-607.

51. Finkbeiner S: Calcium waves in astrocytes-filling in the gaps. Neuron 1992, 8:1101-1108.

52. Wittenberger $\mathrm{T}$, Schaller $\mathrm{HC}$, Hellebrand $\mathrm{S}$ : An expressed sequence tag (EST) data mining strategy succeeding in the discovery of new G-protein coupled receptors. J Mol Biol 2001, 307:799-813.

53. He W, Miao FJP, Lin DCH, Schwandner RT, Wang Z, Gao1 J, Chen JL, Tian H, Ling L: Citric acid cycle intermediates as ligands for orphan G-proteincoupled receptors. Nature 2004, 429:188-193.

54. Regard JB, Sato IT, Coughlin SR: Anatomical profiling of $G$ protein-coupled receptor expression. Cell 2008, 135:561-571.

55. Robben JH, Fenton RA, Vargas SL, Schweer H, Peti-Peterdi J, Deen PMT, Milligan G: Localization of the succinate receptor in the distal nephron and its signaling in polarized MDCK cells. Kidney Int 2009, 76:1258-1267.

56. Aguiar CJ, Andrade VL, Gomes ERM, Alves MNM, Ladeira MS, Pinheiro ACN, Gomes DA, Almeida AP, Goes AM, Resende RR, Guatimosim S, Leite MF: Succinate modulates $\mathrm{Ca}^{2+}$ transient and cardiomyocyte viability through PKA-dependent pathway. Cell Calcium 2010, 47:37-46.

57. Krebs HA: Chemical composition of blood plasma and serum. Annu Rev Biochem 1950, 19:409-430.

58. Nordmann J, Nordmann R: Organic acids in blood and urine. Adv Clin Chem 1961, 4:53-120.

59. Kushnir MM, Komaromy-Hiller G, Shushan B, Urry FM, Roberts WL: Analysis of dicarboxylic acids by tandem mass spectrometry. High-throughput quantitative measurement of methylmalonic acid in serum, plasma, and urine. Clin Chem 2001, 47:1993-2002.

60. Hochachka PW, Dressendorfer RH: Succinate accumulation in man during exercise. Eur J Appl Physiol Occup Physiol 1976, 35:235-242.

61. Forni LG, McKinnon W, Lord GA, Treacher DF, Peron JM, Hilton PJ: Circulating anions usually associated with the Krebs cycle in patients with metabolic acidosis. Crit Care 2005, 9:591-595.

62. Sadagopan N, Li W, Roberds SL, Major T, Preston GM, Yu Y, Tones MA: Circulating succinate is elevated in rodent models of hypertension and metabolic disease. Am J Hypertens 2007, 20:1209-1215.

63. Koizumi S: Synchronization of $\mathrm{Ca}^{2+}$ oscillations: involvement of ATP release in astrocytes. FEBS J 2010, 277:286-292.

64. Koizumi S, Fujisitha K, Tsuda M, Shigemoto-Mogami Y, Inoue K: Dynamic inhibition of excitatory synaptic transmission by astrocyte-derived ATP in hippocampal cultures. Proc Natl Acad Sci USA 2003, 100:11023-11028.

65. Pascual O, Casper KB, Kubera C, Zhang J, Revilla-Sanchez R, Sul J-Y, Takano H, Moss SJ, McCarthy K, Haydon PG: Astrocytic purinergic signaling coordinates synaptic networks. Science 2005, 310:113-116.

66. Deng Q, Terunuma M, Fellin T, Moss SJ, Haydon PG: Astrocytic activation of $A 1$ receptors regulates the surface expression of NMDA receptors through a Src kinase dependent pathway. Glia 2011, 59:1084-1093, Epub 2011 May 4.

67. Schipke CG, Boucsein C, Ohlemeyer C, Kirchhoff F, Kettenmann H: Astrocyte $\mathrm{Ca}^{2+}$ waves trigger responses in microglial cells in brain slices. FASEB J 2002, 16:255-257.

68. Somjen GG: Mechanisms of spreading depression and hypoxic spreading depression-like depolarization. Physiol Rev 2002, 81:1065-1096.

69. Peinado A: Immature neocortical neurons exist as extensive syncitial networks linked by dendrodendritic electrical connections. J Neurophysiol 2001, 85:620-629.

70. Newman EA, Zahs KR: Calcium waves in retinal glial cells. Science 1997, 275:844-847

71. Scemes E, Suadicani SO, Spray DC: Intercellular communication in spinal cord astrocytes: fine tuning between gap-junctions and P2 nucleotide receptors in calcium wave propagation. J Neurosci 2000, 20:1435-1445.

72. Santello M, Bezzi P, Volterra A: TNFa controls glutamatergic gliotransmission in the hippocampal dentate gyrus. Neuron 2011, 69:988-1001.
73. Héja L, Barabás P, Nyitrai G, Kékesi KA, Lasztóczi B, Tőke O, Tárkányi G, Madsen K, Schousboe A, Dobolyi A, Palkovits M, Kardos J: Glutamate uptake triggers transporter-mediated GABA release from astrocytes. PLOS One 2009, 4:e7153.

74. Goubard V, Fino E, Venance L: Contribution of astrocytic glutamate and GABA uptake to corticostriatal information processing. J Physio/ 2011, 589:2301-2319.

75. Agulhon C, Fiacco TA, McCarthy KD: Hippocampal short- and long-term plasticity are not modulated by astrocyte $\mathrm{Ca}^{2+}$ signalling. Science 2010, 327:1250-1254.

76. Fiacco TA, Agulhon C, Taves SR, Petravicz J, Casper KB, Dong X, Chen J, McCarthy KD: Selective stimulation of astrocyte calcium in situ does not affect neuronal excitatory synaptic activity. Neuron 2007, 54:611-626.

77. Henneberger C, Papouin T, Oliet SHR, Rusakov DA: Long-term potentiation depends on release of D-serine from astrocytes. Nature 2010, 463:232-237.

78. Porter JT, McCarthy KD: Hippocampal astrocytes in situ respond to glutamate released from synaptic terminals. J Neurosci 1996, 16:5073-5081.

79. Gee KR, Brown KA, Chen WN, Bishop-Stewart J, Gray D, Johnson I: Chemical and physiological characterization of fluo-4 $\mathrm{Ca}^{2+}$-indicator dyes. Cell Calcium 2000, 27:97-106.

80. ImageJ 1.44 image analysis software. [http://rsbweb.nih.gov/ij/].

\section{doi:10.1186/1471-2202-12-96}

Cite this article as: Molnár et al: Calcium signals in the nucleus accumbens: Activation of astrocytes by ATP and succinate. BMC Neuroscience 2011 12:96.

\section{Submit your next manuscript to BioMed Central and take full advantage of:}

- Convenient online submission

- Thorough peer review

- No space constraints or color figure charges

- Immediate publication on acceptance

- Inclusion in PubMed, CAS, Scopus and Google Scholar

- Research which is freely available for redistribution

Submit your manuscript at www.biomedcentral.com/submit
Biomed Central 